\title{
The Case for Treating Ex-Offenders as a Suspect Class
}

\author{
Ben Geiger $\dagger$
}

\section{INTRODUCTION}

Ex-offenders ${ }^{1}$ occupy one of the most marginalized positions in America. While people with criminal histories have always been reviled and subject to prejudice, several developments in America over the last three decades have escalated the scope and intensity of ex-offenders' marginalization. These historical events include the War on Drugs; the criminalization of poverty, mental illness and addiction; the technological advancement of criminal recordkeeping; and the media promotion and distribution of the image of the pathological criminal through popular culture.

Ex-offenders are not just marginalized, they are also a clear example of repeat losers in pluralist politics. Ex-offenders are often legally disenfranchised. In addition, legislatures impose collateral consequences of conviction on ex-offenders. Collateral consequences are statutes and regulations that inhibit ex-offenders' productive re-entry into society. These statutes testify to ex-offenders' lack of political organization. Furthermore, both ex-offenders' legal disenfranchisement and their de facto political powerlessness are systemic problems. Under current equal protection doctrine, however, ex-offenders receive judicial protection from government prejudice in name only.

Equal protection doctrine fails to protect ex-offenders largely because they are not considered a suspect class for equal protection purposes and therefore do not receive heightened judicial attention when subject to government discrimination. Two major doctrinal obstacles block ex-offenders'

Copyright $(02006$ California Law Review, Inc. California Law Review, lnc. (CLR) is a California nonprofit corporation. CLR and the authors are solely responsible for the content of their publications.

$\dagger \quad$ J.D. Candidate, School of Law, University of California, Berkeley (Boalt Hall) 2006; A.B., Stanford University 1997. 1 would like to thank Goodwin Liu for his guidance and inspiration on this Comment; Jan Vetter, Frank Zimring, and Jesse Choper for their helpful comments; Ryan Tacorda and Sara Sheriff for their review of early drafts; and the editorial staff at the California Law Review for their close reads and sharp feedback.

1. While the preferred term is "formerly incarcerated people," the claim of this Comment extends beyond people actually incarcerated to cover all people with a recorded criminal history. Due to the broader scope of this claim, this Comment uses the term "ex-offenders." 
prima facie claim to treatment as a suspect or semi-suspect class ${ }^{2}$ First, unlike racial minorities, for example, ex-offenders are both responsible for their membership in their classification and morally culpable for it. Ex-offenders could thus be said to deserve whatever sanctions are imposed by the government, or at least not to deserve heightened judicial protection for a status created by criminal conduct. Second, Section Two of the Fourteenth Amendment gives states explicit constitutional permission to disenfranchise ex-offenders. Since political powerlessness is one of the major criteria considered in the suspectness inquiry, it seems illogical to grant heightened judicial protection on the basis of political disempowerment that the Constitution explicitly authorizes.

Neither doctrinal obstacle survives careful analysis. With respect to the moral culpability obstacle, this Comment reasons as follows. Supreme Court caselaw has established that the appropriate suspectness inquiry into moral culpability examines the relevance between individuals' responsibility for their membership in a group and the legal burden imposed upon the group. Collateral consequences are a legal burden constituting punishment and should be imposed through the individualized process of criminal sentencing, according to the Bill of Attainder Clause. If collateral consequences are nevertheless imposed legislatively, at a minimum their burden should be proportional to the responsibility of individual ex-offenders for their criminal histories.

The considerable variation in the moral character of ex-offenders' criminal histories means that lumping arsonists and shoplifters together, for example, is likely to overstretch any but the broadest of moral schema. Most civil legal burdens applied to wide swathes of ex-offenders, then, will be morally disproportionate to the criminal histories of a substantial portion of ex-offenders. Without meaningful judicial protection of ex-offenders, the Equal Protection Clause permits legislatures across the country to pile burden after unexamined burden onto a class that merits heightened scrutiny and for whom these burdens are grossly disproportionate. Such government abuse violates the doctrine and spirit of equal protection.

The Section Two obstacle also collapses. In short, its logic wrongly conflates constitutional approval of political powerlessness with constitutional approval of government prejudice towards the politically powerless. The text and structure of the Constitution, historical evidence of the framers' intent, and the distribution of individual rights among various groups at the time of passage of the Fourteenth Amendment all reveal that government prejudice against individuals in politically powerless groups always violates the Equal Protection Clause.

2. This comment argues that ex-offenders' status warrants giving them heightened judicial protection as a class and leaves for another day the issue of what level of heightened scrutiny to apply to ex-offenders as a class. 
More broadly, this Comment argues that the lack of meaningful judicial safeguard of ex-offenders is doctrinally inconsistent with equal protection, and that a reasonable interpretation of the Equal Protection Clause demands that ex-offenders be accorded suspect status. ${ }^{3}$ While many commentators ${ }^{4}$ have applied considerable pressure to the ossified formalism of current equal protection doctrine, this Comment offers fresh methods of applying the indicia of suspectness and an avenue around the doctrinal barrier to heightened protection of ex-offenders created by Section Two of the Fourteenth Amendment.

Section I describes the conditions ex-offenders face today. Section II reveals the ways that government action exacerbates these conditions by creating collateraI civil consequences of conviction. Section III reviews the current status of equal protection doctrine and section IV argues that exoffenders bear the traditional indicia of suspectness and qualify as a suspect class. Section V concludes with a brief consideration of which statutory restrictions on ex-offenders are most vulnerable to an equal protection challenge.

I

\section{LAND OF SECOND CHANCES?}

Roughly one in five people in America have a criminal history. ${ }^{5}$ Over seven million people are under the active supervision of the criminal justice system. ${ }^{6}$ Every year 650,000 people, enough to populate the City of

3. As Laurence Tribe has explained, the equal protection doctrine is susceptible to interpretation as an antidiscrimination principle and as an antisubjugation principle. See LaURENCE H. TRIBE, AmErican Constitutional LAW $\S 16-22$ (1988). The claim of this paper is based on the antidiscrimination principle in the Fourteenth Amendment because it is both the dominant principle underlying today's equal protection jurisprudence and the more conservative of the two, but not because it is neccssarily the better of the two. Furthermore, if ex-offenders merit heightened scrutiny under an antidiscrimination principle, they would certainly merit it under an antisubjugation principle. For a brief argument that convicted felons are a suspect class under the antisubjugation principle, see Kay Kohler, The Revolving Door: The Effect of Employment Diserimination Against Ex-Prisoners, 26 HASTINGS L.J. 1403 (1974-75).

4. See, e.g., Bruce A. Ackerman, Beyond Carolene Products, 98 Harv. L. Rev. 713 (1985); Dandridge v. Williams, 397 U.S. 471, $519-30$ (1970) (Marshall, J., dissenting); Kenneth L. Karst, The Supreme Court 1976 Term Foreword: Equal Citizenship Under the Fourteenth Amendment, 91 HARV. L. Rev. I (1977); Laurence H. Tribe, The Puzzling Persistence of Process-Based Constitutional Theories, 89 YALE L.J. 1063 (1980).

5. State criminal record repositories held files on more than 59 million individual offenders as of the end of 1999. In addition, the FB1's Criminal Justice Information Service (CJIS) Division had files on more than 43 million individuals as of 2001. The extent of overlap between the two databases is uncleat. Bureau of Justice Statistics, U.S. DeP't of Justice, Use and Management of Criminal History Record Information: A Comprehensive Report, 200 i UpDate 31 -32 (2001), available at http:/www.ojp.usdoj.gov/bjs/pub/pdf/umchri0l.pdf [hereinafter DoJ REPORT 200I]; Debbie A. Mukamal \& Paul N. Samuels, Statutory Limitations on Civil Rights of People with Criminal Records, 30 FordHAM URB. L.J. 1501, 1502 (2003).

6. In 2001, the figure was roughly seven million. Mukamal \& Samuels, supra note 5, at 1502 . 
Baltimore, ${ }^{7}$ come out of jail or prison to face the challenge of re-entering society in a healthy, meaningful and productive capacity.

There has been a fivefold increase in the number of incarcerated individuals over the last thirty years. ${ }^{8}$ Two parallel trends, beginning in the 1970s and continuing today, account for this increase. First, rehabilitation as a penological goal was "publicly and politically discredited." Second, a stronger commitment to incarceration led to the rapid construction of new prisons and a move from indeterminate to determinate sentencing. ${ }^{10}$ Incarceration has grown from a penological tool applied only to "the most violent and incorrigible offenders" to one routinely affecting many persons. ${ }^{11}$ Incarceration and other contact with the criminal justice system is no longer abnormal.

Though it has become much more common, having a criminal history continues to mark individuals for treatment as second-class social, political and economic citizens. Collateral civil consequences of conviction, generated by structural inequality, social stigma, criminal and civil penalties, and improved information technology, combine to create ex-offenders' secondclass citizenship.

While serving time is not necessary to place individuals into the exoffender class, the incarceration experience itself can profoundly disempower inmates beyond their actual sentence and warrants elaboration. To begin, many inmates enter correctional facilities with mental illnesses ${ }^{12}$ and substance abuse problems ${ }^{13}$ that often go untreated during incarceration. ${ }^{14}$ The conditions of incarceration-inmate violence, sexual predation, correctional discipline and abuse, and enforced solitude in higher security facilities $^{15}$ or during administrative detention — can further degrade inmates'

7. Id. at 1501 .

8. Theodore Caplow \& Jonathan Simon, Understanding Prison Policy and Population Trends, in 26 Crime ANd Justice: A Review of Research 63 (Michael Tomry \& Joan Petersilia eds., 1999).

9. Craig Haney \& Philip Zimbardo, The Past and Future of U.S. Prison Policy: Twenty-five Years After the Stanford Prison Experiment, 53 AM. Psychologist 709, $712-18$ (1998).

10. Id.

11. Bruce Western et al., Introduction to Imprisoning America: The Social Effects of Mass InCARCERATION 2-3 (Mary Pattillo et al. eds., 2004).

12. See Jeremy Travis et al., From Prison to home: The Dimensions and Consequences of Prisoner ReEntry 29 (2001), available at http:/www.urban.org/pdfs/from_prison_to_home.pdf (citing studies finding that $8-16 \%$ of the prison population have at least one serious mental disorder and are in need of psychiatric services).

13. Id. at 25 (pointing out that $80 \%$ of the prison population report a history of drug and/or alcohol use).

14. Id. at 29 (summarizing research that $40 \%$ of reported mentally ill state inmates receive no mental health treatment whatsoever).

15. Social psychologist Dr. Craig Haney succinctly describes the actual conditions of this isolation:

To summarize: prisoners in these units live almost entirely within the confines of a 60 - to 80square-foot cell, can exist for many years separated from the natural world around them and removed from the natural rhythms of social life, are denied access to vocational or educational training programs or other meaningful activities in which to engage, get out of 
mental health. ${ }^{16}$ Diseases such as HIV/AIDS, hepatitis $\mathrm{C}$ and tuberculosis also thrive in correctional facilities, infecting inmates at rates far higher than the general population, and limiting ex-offenders' ability to transition into society upon release. ${ }^{17}$

In addition to their damaging mental and physical health effects, penal facilities grossly fail to prepare inmates for re-entering society as stable and productive citizens. Upon release, it is not unusual for a formerly incarcerated person to possess nothing more than a bus ticket and $\$ 125 .^{18}$ The counties to which corrections departments assign inmates for parole are often host to impoverished communities offering little opportunity for gainful employment. ${ }^{19}$

These conditions would be ones to which even the well-educated and well-connected would have difficulty adapting. Affluent college graduates would face awkward questions about unexplained gaps in their resumes. Time away from work would also force affluent college graduates to lose a step or two due to atrophied job skills and industry developments. Ex-offenders, however, are rarely affluent college graduates. The latest comprehensive survey of state inmates, conducted in $199 \mathrm{I}$, revealed that $65 \%$ of state prison inmates had not completed high school, and $53 \%$ earned less than $\$ 10,000$ during the year prior to incarceration. ${ }^{20}$ According to a study of California inmates, $50 \%$ are functionally illiterate ${ }^{21}$ and prior

their cells no more than a few hours a week, are under virtually constant surveillance and monitoring, are rarely if ever in the presence of another person without being heavily chained and restrained, have no opportunities for normal conversation or social interaction, and are denied the opportunity to ever touch another human being with affection or caring or to receive such affection or caring themselves.

Craig Haney, Mental Health Issues in Long-Term Solitary and "Supermax" Confinement, 49 CRIME \& DELINQ. 124, 127 (2003).

16. See id. (illustrating psychological pain, physical suffering, social pathologies, and other mental health effects that "Supermax" inmates experience). But cf. Nicholas Freudenberg, Jails, Prisons, and the Health of Urban Populations: A Review of the Impact of the Correctional System on Community Health, 78 J. URB. HEALTH 214, 224 (2001) (noting conflict in earlier research on long term mental health effects of incarceration).

17. See TRAVIS ET AL., supra note 12, at 28 (reporting that rate of AIDS cases among inmates was five times higher than the rate found in the general population, and that rates of HIV and hepatitis $\mathrm{C}$ infections among state prison inmates were five to seven times and nine to ten times higher, respectively).

18. See id. at 19.

19. See Anthony C. Thompson, Navigating the Hidden Obstacles to Ex-Offender Reentry, 45 B.C. L. Rev. 255, 256-57 (2004).

20. Allen Beck Et Al., U.S. Dep't of Justice, Survey of State Prison Inmates, i99i 3 (1993), available at http://www.ojp.usdoj.gov/bjs/pub/pdf/sospi91.pdf. Furthermore, taking into account that the federal poverty line in 1991 for a household of one was $\$ 6,620$, over one-third of state prison inmates may have been living below the poverty line prior to arrest. For 1991 poverty guidelines, see 56 Fed. Reg. 6589-6861 (Feb. 20, 1991), available at http://aspe.hhs.gov/poverty/ figures-fed-reg.shtml.

21. See Travis et al., supra notc 12, at 12 (citing Cal. Dep't of Corrections, Preventing Parolee failure Program: An Evaluation, 1997 (1997)). 
to incarceration $25 \%$ were unemployed. ${ }^{22}$ Furthermore, the prison vocational training programs that might give inmates a decent chance at securing lawful employment have been cut back severely as more and more correctional resources have been diverted to expansion and construction of new jails and prisons. ${ }^{23}$

The marginalization of ex-offenders also works in negative synergy with the marginalization of minority populations. ${ }^{24}$ Nationally, one out of three African American males and one out of six Latino males can expect to be incarcerated in a state or federal prison during their lifetime, compared to one out of seventeen White males. ${ }^{25}$ One researcher concluded that $75 \%$ of African American men in the District of Columbia will be incarcerated at some point in their lives. ${ }^{26}$ Since racial minorities are already disproportionately underprivileged in this country, the addition of yet another substantial burden only exacerbates the harsh odds minority exoffenders face in making a legal, satisfying living. ${ }^{27}$

Further negative implications of the intersection of race, class and incarceration derive from the marginalization of ex-offenders' communities. Since ex-offenders are often important breadwinners, their innocent families and relatives also suffer from the barriers blocking their re-entry. On top of the significant expense of supporting an inmate, then, inmates' families face a loss of income. ${ }^{28}$ Similarly, since poor communities of color

22. See id. at 31 n.160 (citing Allen Beck Et Al., U.S. Dep't of Justice, Survey of State Prison Inmates, 199 I (1993)).

23. See Thompson, supra note 19 , at 268 .

24. This Comment does not explicitly address the clear and alarming intersection of race and collateral consequences of conviction because this Comment's claim is doctrinal and addresses only facial classifications on the basis of criminal history. The constitutional claim that classifications on the basis of criminal history are racially discriminatory, while valid in the eyes of this author, would rely on a difficult-to-prove disparate impact theory and face the daunting burden of proving legislative intent to discriminate on the basis of race. See Washington v. Davis, 426 U.S. 229 (1976).

25. Thomas P. Bonczar, U.S. Dep't of Justice, Prevalence of lmprisonment in the U.S. Population, 1974-2001 1 (2003), available at http:/www.ojp.usdoj.gov/bjs/pub/pdf/piusp01.pdf. Note that this statistic docs not include incarceration in municipal or county jails. Marc Mauer traces the history of thc "tough on crime" movement from its clear roots in the thinly veiled racism of George Wallace's anti-civil rights thetoric and Richard Nixon's "law and order" campaign in the late 1960's. Marc Mauer, Race to InCARCERAte 50-55 (1999).

26. Donald Braman, Families and Incarceration, in Invisible Punishment: The Collateral Consequences of Mass 1NCARCERATION 117 (Marc Mauer \& Meda Chesney-Lind eds. 2002).

27. Margaret E. Finzen, Note, Systems of Oppression: The Collateral Consequences of Conviction and Their Effects on the Black Communities, 12 Geo. J. ON Poverty L. \& PoL'y 299 (2005).

28. Collect calls from prison, assembling and mailing packages, hotel stays during prison visits, and the cost of child care during visits can take up a large percentage of a family's income. One family interviewed by anthropologist Donald Braman had over $\$ 100$ in prison collect call charges alone, which constituted $20 \%$ of the family's household income. Braman, supra note 26 , at 121 . 
receive a disproportionately high number of ex-offenders, ${ }^{29}$ these communities have even fewer resources for rehabilitation per ex-offender. ${ }^{30}$

With $10 \%$ of the ex-offender population homeless, ${ }^{31}$ and between 70 to $90 \%$ unemployed, ${ }^{32}$ it unfortunately comes as no surprise that the recidivism rate within the first three years of release is above $66 \%{ }^{33}$

The marginalization of ex-offenders that begins in the criminal justice system is amplified at many other points, including political rhetoric. Members of Congress, for example, have identified drug offenders as inhuman or "non-citizens" who have lost all legal protections and civil rights guaranteed others. ${ }^{34}$ One Senator referred to all drug offenders as enemies and a "scourge" on society. ${ }^{35}$ Some Congresspersons referred to low level drug couriers as "animals" and other dealers as "bums," "thugs," "sleazy drug lords" or "merchants of death." 36

The media's coverage of crime leads to disproportionate fear of crime and criminals, and, by association, ex-offenders. ${ }^{37}$ Reports on crime make up one-third of late night news programs, in part because these stories are cheap, simple to film and easy to produce. ${ }^{38}$ Similarly, $4 \%$ of mortalityrelated news text was devoted to tobacco in 1990 while $19 \%$ of deaths that year were actually attributed to tobacco; in contrast $16 \%$ of

29. See TRAVIS ET AL., supra note 12, at 40-41 (pointing out that two-thirds of state prisoners were released in "core" counties that contain central cities of metropolitan areas).

30. See id. at 8 (suggesting that high rates of incarceration and release of ex-offenders into communities may weaken informal social structures such as strong families, individual and social capital, and workforce participation, and thereby increase crime rates).

31. Joan Petersilia, U.S. Dep't of Justice, When Prisoners Return to the Community: Political, Economic, ANd Social Consequences 5 (2000), available at http://www.ncjrs.org/pdffilesl/nij/184253.pdf (citing rate of $10 \%$ homelessness among California parolees).

32. See Travis et al, supra note 12, at 12 (citing Cal. Dep't of Corrections, Preventing Parolee failure Program: An Evaluation, 997 (1997)).

33. According to a 1989 survey by the Bureau of Justice Statistics, two-thirds of people released from prison get rearrested for a felony or serious misdemeanor within three years. See id. at 1 (citing Allen J. Beck \& Bernard E. Shipley, U.S. DeP'T of Justice, Recidivism of Prisoners Released IN $1983(1989)$ ).

34. Margaret P. Spencer, Sentencing Drug Offenders: The Incarceration Addiction, 40 VILL. L. REv. 335, 346 nn.64-5 (1995).

35. Id.

36. Id.

37. Newspaper coverage of death penalty defendants, to use an extreme example, is often taken out of context. See Craig Haney \& Susan Greene, Capital Constructions: Newspaper Reporting in Death Penalty Cases, 4 ANalyses of Soc. Issues \& Pub. Pol'y 129 (2004) (finding that newspaper coverage of death penalty cases tended to cite primarily from law enforcement and prosecutorial sources, foeus very heavily on the characteristics of the crime, and omit or de-emphasize most other aspects of the case, including the defendant's social history, concluding that newspaper coverage of capital crimes may influence public support for the death penalty and undermine public appreciation of the role of social contextual factors in causing crime).

38. MAUER, supra note 25 , at $172-73$. 
mortality-related news text was devoted to illicit drugs and only $1 \%$ of deaths were actually attributed to illicit drugs. ${ }^{39}$

Popular culture also distorts social perception of ex-offenders by promoting an image of the criminal as a pathological maniac. One academic associated crime with hedonism, a "sensual magic" whose primary function is to give perpetrators personal pleasure. ${ }^{40}$ As one reviewer described it, the book "insists that we take seriously the satisfactions that disreputable and depraved acts of predation can bring to those who commit them."41

\section{II}

\section{GOVERNMENT BARRIERS TO REINTEGRATION}

State and federal governments maintain a massive information system to identify and, in some instances, even locate ex-offenders for a variety of restrictive purposes. These purposes include regulating ex-offenders' employment and housing opportunities, welfare eligibility, access to higher education, ability to get a driver's license, and right to vote. This section briefly describes many of the ways in which the government intervenes to perpetuate the second-class citizenship of ex-offenders. The harshness of these state-imposed barriers suggests that heightened judicial oversight is necessary to ensure that the public safety rationale behind many of these restrictions is both legitimate and well served by the law at-issue.

\section{A. Access to Criminal Records}

Underlying the increased incidence of government barriers and restrictions on ex-offenders is a recent increase in the availability of criminal records. Between 1984 and 1999, the number of individuals with state criminal histories almost doubled from 30.3 million to more than 59 million. ${ }^{42}$ Simply amassing and maintaining this volume of criminal records requires a phenomenal expenditure of government resources. ${ }^{43}$

Government agencies-from local courthouses to state departments of justice to the FBI-not only distribute these criminal records to the general public, but also turn them over to the private sector which markets them for distribution. The configuration of public and private sources of criminal history information and the rules that govern them vary significantly by state, change frequently, and lack transparency. While a full recitation of state recordkeeping systems is beyond the scope of this paper, a basic

39. Id. at 175 .

40. Symposium, The Social Context of Capital Murder: Social Histories and the Logic of Mitigation, 35 Santa Clara L. Rev. 547, 557 n. 23 (1995) (citing Jack Katz, Seductions of Crime: Moral and Sensual Attractions in Doing Evil (1988)).

41. Id. (citing John Hagan, The Pleasures of Predation and Disrepute, 24 L. \& Soc'y Rev. 165, 165 (1990)).

42. DOJ REPORT 200I, supra note 5, at 30-31.

43. See id. at $23-33$. 
understanding of how easily investigators may access criminal records is useful.

As Table 1 demonstrates, more than half the states allow internet access to some or all criminal records. ${ }^{44}$ Fourteen states allow internet access to all criminal records, while another fourteen allow access only to criminal records of people still incarcerated or under supervision of the criminal justice system. In addition, an entire industry of private companies, including Choicepoint, LexisNexis, and Westlaw, contract with local government entities in order to provide the public with internet access to criminal records for a modest fee. ${ }^{45}$ Interested parties can generally obtain access to an individual's arrest and conviction history, including the disposition of each encounter, for about twenty dollars and a few minutes online. ${ }^{46}$

Some states have enacted regulations regarding employers and their use of criminal history information for employment decisions. These regulations often go unenforced against the employers and the private criminal history information providers. ${ }^{47}$ Initial research suggests these regulations are especially difficult to enforce since, in order for an applicant to know that a rejection was based on the use of prohibited criminal history information, either the applicant would have to sue and obtain subpoena power to see the job application information or the employer would have to freely admit the illegal basis for rejecting the applicant. ${ }^{48}$ Furthermore, state and

44. Laura John, Casualties of War: a Discussion of California's Legislative Response to the Collateral Consequences of the War on Drugs in the Employment Context 28, n.153 (2005) (unpublished manuscript, on file with The California Law Review) (noting that Florida charges twenty-three dollars and Washington fourteen dollars for access to criminal records online).

45. See id. at 29.

46. See id. at 29-35. This statement is also based on the author's personal experience running hundreds of criminal records backgronnd checks as an investigator working on death penalty postconviction litigation from 1998 to 2002 .

47. The situation in California is illustrative. California officially prohibits employers from inquiring about arrests not leading to convictions, drug convictions dismissed by successful completion of drug diversion, misdemeanor convictions where probation has been successfully completed, convictions whose disposition or release is more than seven years old, and expunged, sealed or purged convictions. See Cal. Civ. Code $\S 1786.18$ (Deering 2005); CAL. LAB. CoDE $\S 432.7$ (Deering 2005). Unlike other states, however, California has no central state criminal records repository, and only five out of fifty-eight counties allow Choicepoint, one of the major private purveyors of criminal history information, to receive this information electronically. Choicepoint therefore sends out "runners" to the other fifty-three counties to manually retrieve criminal history information and build its own private database of criminal records. This has two significant consequences: (1) the manual runners retrieve for Choicepoint arrests not leading to convictions as well as convictions older than seven years, despite the fact that employers are not legally allowed to use this information; and (2) because this proprietary database cannot, of course, be updated with reasonable frequency, crucial updates to individuals' criminal history information, such as sealings, expungements, dismissals of criminal charges, reductions of felonies to misdemeanors or drug diversions do not makc it into the criminal histories received by employers. Public records databases maintained by LexisNexis and Westlaw are similarly problematic. See JoHN, supra note 44, at 29-31.

48. See JoHN, supra note 44 , at 35-37. 
federal administrations are unlikely to face political pressure to devote their scarce resources to enforcement of these laws.

Table 1

Number of States Allowing Internet Access to Criminal Records ${ }^{49}$

\begin{tabular}{|c|c|l|c|}
\hline $\begin{array}{l}\text { Some Level of } \\
\text { Online Access to } \\
\text { Criminal Records }\end{array}$ & $\begin{array}{l}\text { Unrestricted Ac- } \\
\text { cess to All Crimi- } \\
\text { nal Records }\end{array}$ & $\begin{array}{l}\text { Restrieted Ac- } \\
\text { cess: Only Records } \\
\text { of People Serving } \\
\text { Sentences (includes } \\
\text { probation and pa- } \\
\text { role) }\end{array}$ & $\begin{array}{l}\text { Restricted Ac- } \\
\text { cess: Only Records of } \\
\text { Pcople Incarcerated } \\
\text { at Time of Inquiry }\end{array}$ \\
\hline 28 & 14 & 6 & 8 \\
\hline
\end{tabular}

As Table 2 demonstrates, less than a third of states allow ex-offenders to clear their criminal histories. Of this group, only thirteen allow those with cleared histories to legally deny the existence of any conviction. Furthermore, clearing a criminal history, called expungement in many states, can be a limited remedy. In the case of California, expungement does not erase an individual's criminal history, but rather replaces the term "Conviction" in the disposition of the crime as recorded on the rap sheet with "Dismissed in Furtherance of Justice." remains fully available.

Table 2 also reveals that one out of five states do not allow someone who was arrested but not convicted to prevent employers or landlords from viewing that arrest. Moreover, of the states that allow some shielding of arrest records, one in four of these states prohibit someone from denying their arrest, even if the arrest did not lead to a conviction and the arrest has been legally cleared from their record. The criminal justice system records and publishes criminal histories, in perpetuity, for large numbers of people found innocent by that same criminal justice system. More remarkably, as discussed below, nearly $80 \%$ of states allow public and private employers to base employment decisions on arrests not leading to conviction.

The internet has revolutionized the availability of criminal history information for employment and other decisions. Individuals' criminal records are generally cheaply and instantly available online. Government regulation of this access is thus far largely inconsistent and under-enforced. Finally, as discussed in Section IV.B.1.a below, once arrested or convicted of a crime, removing the record or mitigating its impact can be difficult and ineffective. Upon release, a formerly incarcerated person wears a digital scarlet letter.

49. Mukamal \& Samuels, supra note 5, at 1510-11.

50. East Bay Community Law Center, Expungement Training at Boalt Hall (Fall 2004); See also Cal. Penal Code $\S 1203.4$ (Deering 2006) 
Table 2

Number of States Allowing Clearing of Criminal Records ${ }^{51}$

\begin{tabular}{|c|c|c|c|}
\hline $\begin{array}{l}\text { Number of States } \\
\text { That Allow Ex- } \\
\text { pungement or } \\
\begin{array}{l}\text { Sealing of Arrests } \\
\text { Not Leading to } \\
\text { Conviction }\end{array}\end{array}$ & $\begin{array}{l}\text { Number of States } \\
\text { That Allow Denial } \\
\text { of Expunged/Sealed } \\
\text { Arrests Not Leading } \\
\text { to Conviction }\end{array}$ & $\begin{array}{l}\text { Number of States } \\
\text { That Allow Ex- } \\
\text { pungement or Seal- } \\
\text { ing of Convictions }\end{array}$ & $\begin{array}{l}\text { Number of States } \\
\text { That Allow Denial } \\
\text { of Expunged or } \\
\text { Sealed Convic- } \\
\text { tions }\end{array}$ \\
\hline 40 & 29 & 16 & 13 \\
\hline
\end{tabular}

\section{B. Employment}

Ex-offenders face three types of barriers to employment upon release: restrictions on public employment, restrictions on occupational licensing, and discrimination by private employers. ${ }^{52}$

\section{Public Employment}

As Table 3 shows, most states (thirty-six) do not have explicit policies regarding the treatment of criminal histories in public hiring decisions. Of the fourteen that have adopted policies, twelve states prohibit government employers from considering arrests that do not lead to convictions. Unless applicants have had their arrest records sealed or expunged and live and work in a state that prohibits government agencies from viewing sealed or expunged arrest records, the government agency may be in the dubious position of being able to view, but not consider, these arrest records..$^{53}$

The fourteen states that have adopted policies regarding the use of criminal histories in public hiring decisions all attempt to tailor employment decisions to the individual applicant. Most of these states have enacted broad but weak anti-discrimination statutes. The statutes generally consist of a prohibition on the denial of employment "solely on the basis" of an applicant's criminal history, followed by various exceptions. ${ }^{54}$ One common type of exception is for crimes which "directly" or "substantially"

51. Mukamal \& Samuels, supra note 5, at 1509-1510.

52. Reduced job qualifications also limit employment opportunities. In addition to missing out on the typical increase in real wages which most workers experience in their twentics and thirties, exoffenders experience an estimated wage penalty, relative to comparably qualified workers, of 10-20\%. For an excellent discussion of this and other handicaps to employment qualification, see TrAviS ET AL., supra note 12, at 32 . While the effects of reduced job qualifications are severe, providing robust job training and placement programs to counteract this impact involves an ex-offender's affirmative right to employment training. Such a right, though worthy of discussion and integral to a more robust vision of citizenship than contemplated under the Slaughterhouse Cases, is beyond the scope of the antidiscrimination principle proposed in this papcr.

53. E.g., Cal. LaB. CodE $\$ 432.7$ (f)(1)-(2) (Deering 2005).

54. E.g., Haw. Rev. Stat. Ann. \$ 831-3.1 (Michie 2004); 18 Pa. Cons. Stat. Ann. $\$ 9124$ (a) (West 2005) ("shall not preclude"); N.M. STAt. ANN. § 28-2-3 to -6 (Michie 2005); Wash. Rev. CodE ANN. $\S 9.96 \mathrm{~A} .020, .030, .060$ (West 2005 ). 
relate to the duties of the available job position. ${ }^{55} \mathrm{~A}$ few states require the public employer to consider the nature of the crime, its relation to the job type, the degree of rehabilitation, and the time elapsed since disposition or release. ${ }^{56}$ The second common type of exception is a list of enumerated job types or convictions to which the anti-discrimination principle simply does not apply. Enumerated job types typically include police officers, teachers, childcare providers, healthcare providers, banking or insurance employees, and private detectives. Typical enumerated convictions include child molestation or abuse, sex crimes, felonies, felonies of moral turpitude, and misdemeanors of moral turpitude. ${ }^{57}$

\section{Occupational Licensing}

In addition to their own hiring policies, governments affect employment of ex-offenders through occupational licensing rules. To become an ambulance driver, billiard room employee, attorney, physician, pharmacist, nurse, barber, embalmer, septic tank cleaner, real estate professional, accountant, contractor, or purveyor of alcohol, to name a few sample professions, many states require a license. ${ }^{58}$ As Table 3 demonstrates, the majority of state governments allow their occupational licensing boards unrestricted use of criminal history information in their licensing decisions. Occupational licensing agencies generally consider an applicant's criminal record through some sort of inquiry into the "character" of the applicant, though some licensing agencies explicitly list criminal records as a factor for license consideration. ${ }^{59}$

New York state, which has one of the strongest statutory commitments to rehabilitation, faced one of the great ironies of occupational licensing restrictions when the New York Times reported the story of a successful graduate from a prison vocational training program in barbering who could not get a license due to restrictions imposed by the state licensing board. ${ }^{60}$ This case illustrates how even state governments with firm commitments to rehabilitation badly mismanage the clash of competing policy interests. This is unsurprising given the near complete silence of exoffenders' voices in the political arena.

55. E.g., Haw. Rev. Stat. ANN. $\$ 831-3.1$ (LexisNexis 2004); 18 PA. Cons. Stat. ANn. $\S$ 9124(a) (West 2005) ("shall not preclude"); N.M. STAT. ANN. § 28-2-3 to -6 (Michie 2005); WASH. ReV. Code ANn. $\$ 9.96$ A.020, .030, .060 (West 2005).

56. E.g., ConN. Gen. Stat. ANN. $\$ \S 46 a-80(d), 31-51$ i (West 2005).

57. E.g., Haw. Rev. Stat. ANN. \$ 831-3.1 (LexisNexis 2004).

58. Bruce E. May, The Character Component of Occupational Licensing Laws: A Continuing Barrier to the Ex-Felon's Employment Opportunities, 71 N.D. L. REv. 187, 191 (1995).

59. Id. at 193-95.

60. Avi Brisman, Double Whammy: Collateral Consequences of Conviction and Imprisonment for Sustainable Communities and the Environment, 28 WM. \& MARY ENVTL. L. \& PoL'Y Rev. 423, 423 (2004) (citing Clyde Haberman, Ex-Inmate Denied Chair (and Clippers), N.Y. Times, Feb. 25, 2003, at B1). 


\section{Private Employers}

Five states-Hawaii, Kansas, New York, Pennsylvania and Wisconsin-statutorily limit private employers' hiring discretion with respect to applicants with criminal convictions. The statutes generally restrict employers' use of criminal history information in employment decisions to criminal history which is rationally, ${ }^{61}$ reasonably, ${ }^{62}$ directly, ${ }^{63}$ substantially, ${ }^{64}$ or simply ${ }^{65}$ related to the job sought. In addition, some statutes employ further procedural protection either for the applicant (in the form of a right to receive a written copy of the reason for denial of a job ${ }^{66}$ or even a prohibition on inquiry into criminal history until a tentative job offer has been made) ${ }^{67}$ or the employer (in the form of limited liability for negligent hiring). ${ }^{68}$

These statutes provide considerably more protection than those in the other forty-five states, particularly in light of the fact that the private sector provides more jobs than the public sector. Evidence suggests, however, that these statutes are severely underutilized, for lack of attomey's fees provisions $^{69}$ and familiarity among ex-offenders. ${ }^{70}$ Several statutes also carve out exceptions for various job categories, similar to the exceptions carved out for public employment positions discussed above.

These statutes suggest that legislative victories for ex-offenders are possible. The limited number of states enacting legislation, as well as the considerable problems with the legislation that has been enacted, however, reveal the overall absence of political voice among ex-offenders.

61. Haw. Rev. Stat. ANn. $\$ 378-2.5$ (LexisNexis 2004)

62. KAN. STAT. ANN. $§ 22-4710(f)$ (2005).

63. N.Y. EXEC. LAW $\S 296(15)$ (McKinney 2005); N.Y. CORRECT. LAW $\S \S 750-54$ (McKinney 2005).

64. Wis. Stat. ANN. $\S 111.335$ (West 2005).

65. 18 Pa. Cons. Stat. ANN. $\$ 9124$ (West 2005).

66. 18 Pa. Cons. STAT. ANN. $\$ 9124$ (West 2005).

67. Haw. Rev. Stat. ANN. § 378-2.5 (LexisNexis 2004).

68. Kan. Stat, ANN. $\S 22-4710(f)$ (West 2005).

69. 18 Pa. Cons. Stat. ANN. §9I24 (West 2005)

70. See National. Hire Network, Prohibiting Employment Discrimination Based Solely on CRIMinal Histories 7 (2005) (unpublished letter, on file with The California Law Review) (documenting interviews with Pennsylvania legal aid and state anti-discrimination agency employees on lack of awareness of statute among ex-offenders); Haw. Civil Rights Comm., ANNuAl RePORT 17 (2002), available at http://hawaii.gov/labor/reports.shtml (reporting that $6 \%$ of employment discrimination complaints were brought on the basis of arrest or conviction history discrimination). 
Table 3

States Without Restrictions on the Use of Criminal History Information in Employment Decisions, by Type of Decisionmaker. ${ }^{71}$

\begin{tabular}{|l|c|c|}
\hline & $\begin{array}{l}\text { Unrestricted Use of Arrests not Leading to } \\
\text { Convictions }\end{array}$ & $\begin{array}{l}\text { Unrestricted Use of } \\
\text { Convictions }\end{array}$ \\
\hline $\begin{array}{l}\text { Public } \\
\text { Employers }\end{array}$ & 38 & 36 \\
\hline $\begin{array}{l}\text { Licensing } \\
\text { Boards }\end{array}$ & 39 & 31 \\
\hline $\begin{array}{l}\text { Private } \\
\text { Employers }\end{array}$ & 41 & 45 \\
\hline
\end{tabular}

\section{Public Housing}

The federal Department of Housing and Urban Development (HUD) funds public housing but grants to local housing authorities wide discretion regarding eligibility criteria. Although the federal government requires housing authorities to permanently ban people convicted of certain sex offenses or of methamphetamine production on public housing property, ${ }^{72}$ housing authorities have the discretion to deny eligibility to anyone who has engaged in drug-related, violent, or other criminal activity that would adversely affect the health, safety or right to peaceful enjoyment of the premises of other residents. Housing authorities can also exclude anyone previously evicted from public, federally assisted, or Section 8 housing because of drug-related criminal activity within the past three years. ${ }^{73}$ Housing authorities may determine (1) which crimes make a person ineligible for housing prograns, (2) whether they will consider arrests not leading to convictions, (3) how long to extend ineligibility of people with criminal records, and (4) what, if anything, qualifies as rehabilitation for the purposes of lifting bars to public housing. ${ }^{74}$ Research suggests that local housing authorities frequently use these discretionary powers to exclude ex-offenders from public housing ${ }^{75}$ and to exclude them for considerable or even indefinite periods. ${ }^{76}$

71. See Mukamal \& Samuels, supra note 5, at 1503-1505.

72. 42 U.S.C. $\S 13663$ (a) (2000), 42 C.F.R. $\$ 960.204(a)(3)-(4)(2005)$.

73. 42 U.S.C. $\S 13661$ (2000), 24 C.F.R. $\S 960.204$ (2005).

74. Id.

75. See Human Rights Watch, No Second Chance: People with Criminal Records Denied Access to Public Housing 3, available at http://www.soros.org/initiatives/justice/ articles_publications/publications/no_20041208/nosecond.pdf.

76. Exclusions for misdemeanors among housing authorities in seven major cities ranged from threc to ten years, felonies from three to twenty years, and serious felonies from three years to life. See id. at 51 . 


\section{Welfare Benefits}

The Personal Responsibility and Work Opportunity Reconciliation Act of $1996^{77}$ permanently prohibits anyone convicted of a drug-related felony from receiving federally-funded cash assistance (i.e., Temporary Assistance for Needy Families or "TANF") and food stamps. ${ }^{78}$ Although the law contains on opt-out procedure for states, only eleven have opted out of the law entirely. ${ }^{79}$ The felon exclusion in this Act was debated for a mere two minutes on the floor of the Senate. ${ }^{80}$

\section{E. Driving Privileges}

The 1992 Department of Transportation and Related Agencies Appropriation $\mathrm{Act}^{81}$ requires the Department of Transportation withhold $10 \%$ of certain federal highway funds unless a state either (1) enacts and enforces a law suspending for at least six months the driver's license of an individual convicted of any drug offense, ${ }^{82}$ or (2) the governor certifies that he or she opposes the suspension rule and that the state legislature has adopted a resolution expressing its opposition to the rule. ${ }^{83}$ While twentyseven states have opted out of the suspension, the remaining twenty-three adopted the six-month suspension rule or a variation on it. Seventeen states give a six-month penalty for a first conviction, while four states give a penalty of greater than six months and two states give a penalty of less than six months. $^{84}$

Ex-offenders thus face a government rule regime that facilitates their easy identification by potential employers and landlords, denies them occupational licenses and other employment opportunities, linuits their access to public housing, restricts their receipt of loans for higher education and welfare assistance, and suspends their driving privileges. This rule regime is not nerely the government stepping aside to allow private discrimination against ex-offenders, but rather active government construction and maintenance of excessive barriers blocking ex-offenders' re-entry into productive society.

\footnotetext{
77. Pub. L. No. 104-193, 110 Stat. 2168 (1996).

78. 21 U.S.C. $\$ 862 \mathrm{a}(\mathrm{a})(2000)$.

79. See Mukamal \& Samuels, supra note 5, at 1506-08.

80. Gwen Rubinstein \& Debbie Mukamal, Welfare and Housing: Denial of Benefits to Drug Offenders, in INVISIBLE PUNISHMENT, supra note 26, at 42.

81. Pub. L. No. 102-388, 106 Stat. 1520 (1992).

82. Drug offense is defined as any criminal offense involving "the possession, distribution, manufacturc, cultivation, sale, transfer, or attempt or conspiracy to posscss, distribute, manufacture, cultivate, sell, or transfer any substance the possession of which is prohibited under the Controlled Substances Act; or the opcration of any motor vehicle under the influence of such a substance." 23 U.S.C. $\S 159(\mathrm{c})(2)(2000)$.

83. 23 U.S.C. $\$ 159$ (a) (2000).

84. See Mukamal \& Samuels, supra note 5, at 1515-16.
} 
Despite this harsh government discrimination against ex-offenders, the constitutional protection most readily suited to temper this discrimination, namely equal protection, is largely inert.

\section{III \\ Equal Protection Doctrine}

\section{A. Equal Protection Analysis in General}

The Equal Protection Clause of the Fourteenth Amendment protects individuals from discriminatory government classification, it reads: "No State shall...deny to any person within its jurisdiction the equal protection of the laws." ${ }^{85}$

Laws, however, must necessarily distinguish among persons categorizing, for example, those who do from those who do not drive over seventy miles per hour. In order to decide which classifications are discriminatory, the Supreme Court has developed an interpretive analysis in which the nature of the government classification and whether it impinges on a fundamental right ${ }^{86}$ determines the level of scrutiny the judiciary applies to challenged legislation. ${ }^{87}$

In choosing the level of scrutiny to apply to government classifications, the Court looks at whether the classified group possesses the traditional indicia of suspectness: immutability, political powerlessness, and a history of class-based discrimination, among others discussed below. If legislation classifies according to membership in a group that has these indicia, then courts must review this legislation with heightened scrutiny. ${ }^{88}$

The traditional indicia of suspectness test has generated a tiered hierarchy of scrutiny. Where laws distinguish by race, ${ }^{89}$ national origin, ${ }^{90}$ or alienage, ${ }^{91}$ judges must review them with strict scrutiny. In order to survive strict scrutiny, laws must be narrowly tailored to further a compelling government interest. ${ }^{92}$ Where laws distinguish according to economic and social characteristics, however, judges are to consider only whether the laws

85. U.S. CoNST. amend. XIV, § 1.

86. See, e.g., Shapiro v. Thompson, 394 U.S. 618 (1969) (striking state welfare law with one year residency requirement for infringing on the right to travel in violation of the Equal Protection Clause).

87. United States v. Carolene Products Co., 304 U.S. 144, 152-53 (1938).

88. See Mass. Bd. of Ret. v. Murgia, 427 U.S. 307, 313-314 (1976); James A. Kushner, Government Discrimination: Equal Protection Law and Litigation, $\$ 5: 1$ (2005).

89. See Korematsu v. United States, 323 U.S. 214 (1944) (declaring race and national origin suspect classifications).

90. See $i d$.

91. See Graham v. Richardson, 403 U.S. 365 (1971) (holding alienage a suspect classification); but see Bernal v. Fainter, 467 U.S. 216 (1984) (finding alienage is a suspect classification except where the classification is used as a requirement for serving in political functions, such as political office or teaching); see generally TRIBE, supra note 3, at § 16-23.

92. See, e.g., Grutter v. Bollinger, 539 U.S. 306 (2003). 
rationally relate to a legitimate government interest. ${ }^{93}$ Under this minimal scrutiny courts are required to step in and supply "any conceivable rational basis" to justify legislation, even where the government fails to supply such a basis. ${ }^{94}$ Unsurprisingly, judges applying rational basis review rarely overturn challenged legislation. In contrast, few laws stand up under strict judicial scrutiny.

The Court has employed two intermediate levels of review between the extremes of strict scrutiny and rational basis review. Classifications based on gender ${ }^{95}$ and illegitimacy ${ }^{96}$ trigger intermediate judicial scrutiny, under which the law must be necessary to an important government interest. $^{97}$ In certain cases, the Supreme Court has also overturned legislation under minimum scrutiny despite the fact that it could readily be justified by a conceivable rational basis and even a legitimate state interest. ${ }^{98}$ These cases suggest the existence of an unofficial fourth tier of judicial scrutiny, often referred to as "rational basis with teeth." 99

\section{B. Determining the Level of Scrutiny}

As described above, for a group to receive heightened scrutiny as a suspect class, it must meet the "traditional indicia of suspectness," a phrase coined by Justice Powell in San Antonio Independent School District $v$. Rodriguez. ${ }^{100}$ The doctrine behind the traditional indicia of suspectness is notoriously slippery. Commentators have described it as "haphazard" and "creating an analytical muddle." 101 This Part will review the historical development of the suspectness doctrine by tracking the development of the various indicia of suspectness - the Carolene Products formulation, immutability, a history of class-based discrimination, political powerlessness, and inherent suspicion.

\section{Carolene Products Rationale}

The Fourteenth Amendment was ratified to guarantee the victory of the Union against slave states. Employed sporadically to protect individual

93. See Williamson v. Lee Optical, Inc., 348 U.S. 483 (1955).

94. See, e.g., FCC v. Beach Commc'n, Inc., 508 U.S. 307, 309 (1993).

95. Craig v. Boren, 429 U.S. I 90 (1976).

96. Mathews v. Lucas, 427 U.S. 495 (1976).

97. Id.

98. See, e.g., Plyler v. Doe, 457 U.S. 202 (1982); City of Cleburne v. Cleburne Living Ctr., Inc., 473 U.S. 432,478 (I985).

99. David O. Stewart, A Growing Equal Protection Clause?, 7I A.B.A. J. 108, 112-14 (1985) (quoting Victor Rosenblum in discussion of City of Cleyburne).

100. 41 I U.S. 1,28 (I973).

101. Thomas W. Simon, Suspect Class Democracy: A Social Theory, 45 U. Miami L. Rev. 107, I4I (1990). 
rights over the next sixty years, ${ }^{102}$ courts turned with renewed interest to the Equal Protection Clause as a tool for judicial protection of individual rights in 1938, after the era of economic substantive due process came to an end. ${ }^{103}$

Justice Stone first suggested in Carolene Products that courts might apply special scrutiny to classifications based on certain group traits. ${ }^{104}$ The third paragraph of footnote four of Carolene Products proposed that "prejudice against discrete and insular minorities may be a special condition, which tends seriously to curtail the operation of those political processes ordinarily to be relied upon to protect minorities, and which may call for a correspondingly more searching judicial inquiry." 105 Justice Stone thus suggested that where groups are repeat losers in pluralist politics not because of their minority status in a majoritarian democracy but because of prejudice, the judiciary may set aside its traditional deference towards legislation and more rigorously review it. ${ }^{106}$

The footnote-four rationale next appeared in the infamous Korematsu case ${ }^{107}$ There the Court upheld the military's decision to force Japanese Americans living in the western United States into detention camps. ${ }^{108} 1 \mathrm{n}$ the course of the decision, however, the Court declared that government classifications on the basis of race would be reviewed with "the most rigid scrutiny," 109 thus employing Justice Stone's rationale with respect to racial classifications. Seventeen years after Carolene Products, in Brown v. Board of Education in 1954, the Court struck down a racial classification under the Carolene Products rationale. ${ }^{110}$ In the mid-1960s, the Court struck down an anti-adultery statute limited to African American-White liaisons ${ }^{111}$ and an anti-miscegenation statute by employing strict scrutiny against racial classifications. ${ }^{12}$

102. See e.g., Strauder v. Wcst Virginia, 100 U.S. 303 (1880); Yick Wo v. Hopkins, 118 U.S. 356 (1886)

103. In West Coast Hotel Co. v. Parrish, 300 U.S. 379 (1937), the Supreme Court discarded the doctrine of economic substantive due process, as epitomized in Lochner v. New York, 198 U.S. 45 (1905). Robert Cover has argued that, in the vacuum of judicial power created by the demise of economic substantive due process, the Court fortified the equal protection doctrine as an alternative foundation of judicial power. Robert M. Cover, The Origins of Judicial Activism in the Protection of Minorities, 91 YALE L.J. 1287 (1982); see also, Ackerman, supra note 4, at 714.

104. United States v. Carolene Products Co., 304 U.S. 144 (1938).

105. Id. at 152 n.4.

106. See generally Cover, supra note 103 .

107. Korematsu v. United States, 323 U.S. 214 (1944).

108. Id. at $220-21$.

109. Id. at 216 .

110. See Louis Lusky, Footnote Redux: A Carolene Products Reminiscence, 82 Colum. L. Rev. 1093, 1104 (1982).

111. McLaughlin v. Florida, 379 U.S. 184, 192 (1964).

112. Loving v. Virginia, 388 U.S. 1 (1967). 
The Court found the related government action of classifying on the basis of national origin or ancestry justified heightened judicial review in Oyama v. California, where it struck down a California statute preventing the purchase, use, lease, and transfer of real property in California by Japanese aliens not eligible for naturalization. ${ }^{113}$ This decision was not much of a stretch for the Court given the similarities between race and ancestry as group traits and the Court's precedent of striking classifications based on ancestry. In 1886, for example, the Court struck down a San Francisco ordinance prohibiting operation of laundries by people of Chinese ancestry in Yick Wo v. Hopkins. ${ }^{114}$

As part of the civil rights movement and the social and cultural unrest of the 1960s and 70s, advocates pushed the Court to expand its protective ambit to include other suspect groups. ${ }^{115}$ In Graham v. Richardson the Court began to expand the universe of suspect classes in response to this pressure by striking down Arizona and Pennsylvania statutes restricting the eligibility of legal aliens for public assistance and declaring that, "Aliens as a class are a prime example of a 'discrete and insular' minority . . f for whom such heightened judicial solicitude is appropriate."116 This was the first invocation of Justice Stone's "discrete and insular" phrase, and it was unfortunately unaccompanied by explanation of why aliens constitute a discrete and insular minority.

Professor John Hart Ely has offered perhaps the most developed elaboration of the footnote-four rationale. ${ }^{17}$ Unequal legislative treatment (regarding benefits to which there is no fundamental constitutional right) is problematic, he argues, where it is motivated by government prejudice towards the disadvantaged group. ${ }^{118}$ Since identifying prejudice, however, is an exceptionally difficult task, courts should scrutinize government classifications where the process of legislating or administering laws is defective because deviations from legitimate decision-making processes are suggestive of prejudicial motivations. ${ }^{119}$ Professor Ely views the protections "ordinarily to be relied upon to protect minorities" as guarantees of processual fairness. ${ }^{120}$ Classifications that disadvantage discrete and insular minorities raise suspicion of process defects because legislators elected by democratic majorities are unlikely to have much personal contact with socially isolated minorities and are therefore more likely to have unmediated

\footnotetext{
113. Oyama v. California, 332 U.S. 633, 644-47 (1948).

114. 118 U.S. $356(1886)$.

115. See Suzanne B. Goldberg, Equality Without Tiers, 77 S. Cal.1F. L. Rev. 481, 498-500 (2004).

116. Graham v. Richardson, 403 U.S. 365, 372 (1971) (internal citations omitted).

117. John HaRt Ely, Democracy and Distrust (1980).

118. See, e.g., id. at 144-45.

119. See, e.g., id. at 157 .

120. ELY, supra note 117 at 157.
} 
negativity or hostility towards these minorities and/or to undervalue harms they experience. ${ }^{121}$

\section{Immutability}

Just two years after Graham v. Richardson, the Court gave several additional explanations for why certain classes merited heightened judicial protection. In Frontiero $v$. Richardson, ${ }^{122}$ the Court struck down a military benefits scheme that required women service members to prove spousal dependency while giving men an automatic presumption of spousal dependency.

A plurality of the Court argued that classifications on the basis of gender warranted strict judicial scrutiny, presenting three reasons for this view. First, the Court found that women have suffered a history of discrimination on the basis of their gender "which, in practical effect, put women, not on a pedestal, but in a cage"123 and was comparable to that suffered by African Americans during the pre-Civil War era. The rights that African Americans were being deprived of included the right to hold office, serve on juries, bring suit, qualify as legal guardians for their children, own property in their own name, and vote. ${ }^{124}$

Second, affirming the formulation in Weber v. Aetna Casualty \& Surety Co., ${ }^{125}$ the Court stated that "an immutable characteristic determined solely by the accident of birth" should not be the basis of legislative classifications because this would violate "the basic concept of our system that legal burdens should bear some relationship to individual responsibility." 26

Lastly, the Frontiero court suggested that women should be considered a suspect class because "the sex characteristic frequently bears no relation to ability to perform or contribute to society." 127 As a result, the Court argued, statutes that distinguish between the sexes "often have the effect of invidiously relegating the entire class of females to inferior legal status without regard to the actual capabilities of its individual members." 128

The plurality view in Frontiero, that gender classifications should be reviewed with strict scrutiny, has never won five votes. A few years later, the Court nevertheless found in Craig v. Boren that gender classifications

\footnotetext{
121. Id, at 160-61.

122. 411 U.S. 677 (1973).

123. Id. at 684 .

124. Id. at 685 .

125. 406 U.S. 164 (1972).

126. Frontiero, 411 U.S. at 686.

127. Id.

128. Id. at 687 .
} 
should be reviewed with intermediate scrutiny, meaning that these classifications must substantially relate to an important government interest. ${ }^{129}$

Frontiero suggested, among other things, that immutability is one basis for treating a group as a suspect class. The dictionary definition of immutable is "not capable or susceptible of change: invariable, unalterable." ${ }^{30}$ Classifications based on unalterable traits, however, raise judicial concern only where the trait is additionally objectionableotherwise intelligence and height might be suspect classifications. Frontiero describes two objectionable strands of immutability, both of which warrant elaboration.

The first objectionable strand of immutability articulated in Frontiero is that individuals are often not responsible for possessing immutable traits because many are accidents of birth. Burdening individuals according to an immutable trait for which they are not responsible violates basic norms of fairness. Thus discrimination against children on the basis of their parents' wrongs is given heightened scrutiny. In Weber $v$. Aetna, for example, the Court overturned a statute preventing unacknowledged non-marital children from collecting worker's compensation benefits from a deceased parent. ${ }^{131}$ In Plyler v. Doe, the Court similarly struck a Texas statute allowing school districts to exclude children of undocumented parents. ${ }^{132}$

The second objectionable strand of classifying according to immutable traits articulated in Frontiero is that immutable traits often bear little relevance to individual ability. This objection has proven especially useful to the Court in striking down gender classifications based on stereotypes regarding women's competence ${ }^{133}$ and contributions. ${ }^{134}$

A third objectionable strand of classifying on the basis of immutable traits comes from Professor Ely's process-based theory of equal protection. Ely highlights the fact that legislators and other government decision makers are rarely members of certain groups defined by immutable characteristics. The impermeability of certain immutable groups by legislators is significant in that it increases the likelihood that legislators will act prejudicially against these groups out of hostility or undervaluation of harm suffered by these groups ${ }^{135}$ for the simple reason that self-serving and

129. Craig v. Boren, 429 U.S. 190 (1976).

130. Webster's Third NeW International Dictionary, Unabridged (1993)

131. Weber v. Aetna Cas. \& Sur. Co., 406 U.S. 164 (1972).

132. See Plyler v. Doe, 457 U.S. 202 (1982).

133. Reed v. Reed, 404 U.S. 71 (1971) (striking down ldaho statute that gave preference to men in serving as the administrator of a deceased's estate when men and women were otherwise equally qualified, because of men's greater business and financial expertise).

134. Weinberger v. Wiesenfeld, 420 U.S. 636 (1975) (striking a section of the Social Security Act allowing widows but not widowers to collect on earnings of deceased spouse because of "archaic and overbroad" stereotype that women's wage earnings were not essential to the family).

135. ELY, supra note 117 , at 159. 
other-harming legislation will never hurt the legislators. ${ }^{136}$ The Court has sometimes adopted a similar theory regarding impermeability. In Massachusetts Board of Retirement v. Murgia, for example, the Court denied that the aged are a suspect class in part because entering old age "marks a stage that each of us will reach if we live out our normal span."137

Many "immutable" traits are actually alterable. Aliens can change their status upon either naturalization or return to their country of origin. Illegitimate children become acknowledged by their biological parents or be adopted. Men and women can take on new sexual or gender identities as transvestite, transsexual, or transgendered persons. Science has even revealed that biological differences among the races are negligible, highlighting the socially constructed nature of divisions according to skin pigmentation and facial structure. All of which begs the significance of immutability qua unalterability.

Unalterability itself, as discussed above, is not an objectionable basis for classification. Rather, unalterability is important because it is a precondition to the objectionable strands of the immutability indicium: irrelevance to individual responsibility, for example, is a less compelling objection if an individual can simply change her disqualifying trait, and impermeability is not a concern if an individual can simply exit the group targeted by prejudiced legislators. The significance of unalterability to the immutability indicia is the extent to which unalterability constitutes a barrier to individual exit from the class rather than the extent to which an unalterable trait is literally unchangeable.

\section{History of Class-Based Discrimination}

In the same 1973 term that it decided Fronterio, the Court decided San Antonio v. Rodriguez. ${ }^{138}$ In Rodriguez the Court upheld a Texas school financing scheme that allowed for significant disparities in per-pupil spending according to school district property tax yield. The Court justified its denial of the plaintiffs' argument that wealth should be a suspect classification by declaring that residents of poorer school districts were not "saddled with such disabilities, or subjected to such a history of purposeful unequal treatment, or relegated to such a position of political powerlessness as to command extraordinary protection from the majoritarian political process." 139 Rodriguez restated Frontiero's emphasis on a history of class-based discrimination.

The paradigm case of a history of class-based discrimination is that experienced by this country's African American population. The Frontiero

136. Id. at 160 .

137. Murgia, 427 U.S. at 313-14 .

138. San Antonio Indep. Sch. Dist. v. Rodriguez, 411 U.S. 1 (1973).

139. Id. at 28 . 
Court compared women's history of discrimination to that of pre-Civil War discrimination against African Americans. Similarly, in upholding Massachusetts's mandatory retirement age of fifty for police officers, the Court rejected the plaintiffs' claim that age is a suspect classification by arguing in part that, "while the treatment of the aged in this Nation has not been wholly free of discrimination, such persons, unlike, say, those who have been discriminated against on the basis of race or national origin, have not experienced a 'history of purposeful unequal treatment' . ..."140 The benchmark against which courts measure a group's history of discrimination is that of African Americans prior to the Civil War.

\section{Political Powerlessness}

Political powerlessness in the Court's analysis is often simply a referent to paragraph three of footnote four in Carolene Products, which suggested heightened scrutiny in instances of government prejudice against discrete and insular minorities because such prejudice "tends seriously to curtail the operation of those political processes ordinarily to be relied upon to protect minorities." ${ }^{141}$ In Johnson v. Robison, for example, the Court denied suspect status to conscientious objectors in the course of upholding their exclusion (in spite of their completion of alternate service) from Veterans' educational benefits. The Court approvingly quoted the district court's opinion, which stated:

Given the solicitous regard that Congress has manifested towards conscientious objectors [by allowing them not to serve], it would seem presumptuous of a court to subject the educational benefits legislation to strict scrutiny on the basis of the 'suspect classification' theory, whose underlying rationale is that, where legislation affects discrete and insular minorities, the presumption of constitutionality fades because traditional political processes may have broken down. ${ }^{142}$

Similarly, in City of Cleburne v. Cleburne Living Center, the Court found that mentally retarded people were not a suspect class because "the distinctive legislative response ... to the plight of those who are mentally retarded demonstrates ... that the lawmakers have been addressing their difficulties in a manner that belies a continuing antipathy or prejudice and a corresponding need for more intrusive oversight by the judiciary."143

The political-powerlessness argument regarding women advanced by the Frontiero court, however, constituted an expansion of the Carolene Products framework of political powerlessness. To begin, women do not

140. Mass. Bd. of Ret., 427 U.S. at 314 (1976) (internal citations omitted).

141. Carolene Products Co., 304 U.S. at 152 n.4.

142. Johnson v. Robison, 415 U.S. 361, 375 (1974) (emphasis added).

143. Cleburne Living Ctr., 473 U.S. at 433. 
constitute an "insular" minority. As mothers, sisters, spouses, and daughters, to limit the discussion to familial relations, women cannot be described as isolated from society (although a fair argument could be made that women are isolated to the extent they are role-bound by social dynamics) or from the empathy of male-dominated legislatures. ${ }^{144}$ Furthermore, from a strictly numerical standpoint, women are also not politically powerless. Under the Carolene Products rationale, the Court could have painted women as unlikely victims of legislative prejudice. The Court countered its own admission that women are not a "small and powerless minority," however, by arguing that women are nevertheless underrepresented in "decisionmaking councils" including the Presidency, Senate, House of Representatives, and Supreme Court. ${ }^{145}$ The Court engaged a more subtle political-powerlessness analysis in Frontiero by taking societal power dynamics beyond legislative prejudice into account.

\section{Inherent Suspicion of the Classification}

The Court has at times suggested that certain classifications are simply inherently suspicious. This analysis is generally applied to racial classifications. The Court has stated that racial classifications are "so seldom relevant" to any legitimate government purpose as to warrant heightened judicial scrutiny. ${ }^{146}$ ln another formulation, the Court has stated that "[c]ertain classifications... in themselves supply a reason to infer antipathy. Race is the paradigm." 147

\section{Whither Suspectness?}

As mentioned in the introduction to this subsection, suspectness doctrine is a muddled area of law. The primary source of confusion comes from not knowing when to apply the various indicia of suspectness to a given classification. While Carolene Products and Rodriguez each offered an arguably comprehensive set of indicia, later cases suggest a lack of any consistent ordering. In Murgia, for example, in refusing to grant suspect status to the class of uniformed police officers over fifty, the Court essentially launched a string of denials at nearly all the indicia. The Court first denied that the class met the Rodriguez factors (disabilities, history of class-based discrimination, political powerlessness), then denied that it had been saddled with disabilities "not truly indicative of their abilities" (a fusion of a Rodriguez indicium and one strand of immutability), added that

144. This is not to deny that women have faced discrimination and hostility from male-dominated legislature for most of U.S. history, but rather to point out that an antidiscrimination principle activated by a group's insularity or isolation will not have an easy case justifying activation on behalf of women.

145. Frontiero v. Richardson, 411 U.S. 677, 686 n.17 (1973).

146. Cleburne Living Ctr., 473 U.S. at 440.

147. Pers. Adm'r of Mass. v. Feeney, 442 U.S. 256, 272 (1979) (upholding state's absolute lifetime hiring preference for veterans against charge of gender discrimination violative of EPC). 
the aged do not constitute a discrete and insular minority, and, as a grand finale, declared that old age was not a classification "sufficiently akin" to other classifications receiving strict scrutiny. ${ }^{148}$

\section{IV}

\section{The Case that Ex-Offenders Qualify as a Suspect Class}

Given the doctrinal ambiguity around suspect classifications, application of the doctrine must be somewhat imprecise. This section attempts the job by first assessing ex-offenders' present treatment in equal protection caselaw and then considering ex-offenders as a potential suspect class along each of the indicia of suspectness discussed above.

\section{A. Ex-Offenders' Current Status Under Equal Protection}

Current equal protection doctrine does not offer heightened scrutiny to ex-offenders. ${ }^{149}$ Courts have stricken collateral consequences of conviction for vagueness, ${ }^{150}$ inconsistency ${ }^{151}$ and deprivation of an opportunity to demonstrate rehabilitation. ${ }^{152}$ Courts have similarly overturned blanket bans on public employment of ex-offenders. ${ }^{153}$ However, courts have generally upheld collateral consequences under rational-basis review where the restrictions are in any way narrowed or targeted to certain types of

148. Murgia, 427 U.S. at 313-14.

149. Richardson v. Ramirez, 418 U.S. 24 (1974); Champion v. Artuz, 76 F.3d 483 (2d Cir. 1996) (applying rational-basis review in sustaining the denial of a conjugal prison visit by a wife due to her status as an ex-offender because this status did not place her in a suspect class).

150. See Smith v. Fussenich, 440 F. Supp. 1077 (D. Conn. 1977) (striking down state law prohibiting felons from employment with licensed detective or security guard agencies on basis of vagueness and arbitrariness of allowing misdemeanants such employment); Miller v. D.C. Bd. of App., 294 A.2d 365 (D.C. 1972) (striking down D.C. board's denial of license to sell costume jewelry on public streets on basis of plaintiff's criminal history of assault, burglary, lareeny, and possession and sale of narcotics because standard of board's review was overly vague).

151. See Miller v. Carter, 547 F.2d 1314 (7th Cir. 1977), aff d, 434 U.S. 356 (1978) (striking down a Chicago ordinance prohibiting the issuance of chauffeurs' licenses to persons convicted of certain violent felonies because the ordinance did not affect convicts of these felonies who already possessed chauffeurs' licenses); Smith v. Fussenich, 440 F. Supp. 1077 (D. Conn. 1977) (striking down state law prohibiting felons from employment with licensed detective or security guard agencies on basis of vagueness and arbitrariness of allowing misdemeanants such employment); Ali v. Div. of Athletic Comm'n of N.Y., 316 F. Supp. 1246 (S.D.N.Y. 1970) (overturning denial of boxing license to Mohammed Ali on basis of single conviction for refusal to serve in military where other boxers with multiple convictions had been granted licenses).

152. See Cronin v. O'Leary, 13 Mass. L. Rep. 405 (Mass. Super. Ct. 2001) (finding that deprivation of significant numbers of employment opportunities and creation of stigma constitute a Fourteenth Amendment liberty interest triggering procedural due process right to hearing prior to permanent bar on employment with Massachusetts Health and Human Services Agency).

153. See Kindem v. City of Alameda, 502 F. Supp. 1108 (N.D. Cal. 1980) (striking down blanket city ban on public employment of ex-felons); Butts v. Nichols, 381 F. Supp. 573 (S.D. Iowa 1974) (striking down ban on any city employment of any ex-felon). 
offenders or government benefits. ${ }^{154}$ Where courts have stricken tailored collateral restrictions on ex-offenders they have often found a substantive due process liberty interest in employment. ${ }^{155}$ In the unusual instances where a court has stricken a tailored collateral consequence for lack of adequate rational relationship between the restriction and the government's interest, ${ }^{156}$ the criminal conviction is often, but not always, ${ }^{157}$ minor, ${ }^{158}$ nonexistent, ${ }^{159}$ or old. ${ }^{160}$ These cases suggest that courts rarely depart from true rational-basis review despite current equal-protection doctrine.

154. See Brown v. Hotel \& Restaurant Employees International Union Local 54, 468 U.S. 491 (1984) (upholding ban on union officials with criminal convictions from collecting dues from casino employees); N.Y. Transit Auth. v. Beazer, 440 U.S. 568 (1979) (upholding transit authority enforcement of ban on employment of drug addicts against persons who successfully completed first year of methadone program); De Veau v. Braisted, 363 U.S. 144 (1960) (upholding ban on union officials with felony convictions from collecting or soliciting dues on waterfront); FW/PBS, Inc. v. City of Dallas, 837 F.2d 1298 (5th Cir. 1988), aff'd in part, rev'd in part, vacated in part, 493 U.S. 215 (I990) (upholding five year exclusion against people convicted of sex or obscenity crimes from sexrelated businesses); Upshaw v. McNamara, 435 F.2d 1188 (1st Cir. 1970) (upholding state law prohibiting appointment of felons to police force); Hill v. City of Chester, No. 92-4357, 1994 WL 463405 (E.D. Pa. 1994) (upholding city council's elimination mayor's administrative assistant who was a rehabilitated two-time ex-offender); Hill v. Gill, 703 F. Supp. 1034, 1037 (D.R.I. 1989) (upholding ban on employment of ex-felons as school bus drivers); Schanuel v. Anderson, 546 F. Supp. 519, 525 (S.D. I11. 1982), aff'd, 708 F.2d 316 (7th Cir. 1983) (upholding ten-year prohibition against ex-felons from employment as security guards); Dixon v. McMullen, 527 F. Supp. 711 (N.D. Tex. 1981) (upholding automatic exclusion of ex-felons from certification as police officers); Carlylc v. Sitterson, 438 F. Supp. 956 (D.N.C. 1975) (upholding dismissal of fireman with previous arson conviction).

155. See Gregg v. Lawson, 732 F. Supp. 849 (E.D. Tenn. 1989) (finding property interest in placement on on-call tow list and insufficient government interest to remove ex-felon currently on list); Lewis v. Ala. Dep't Pub. Safety, 831 F. Supp. 824 (M.D. Ala. 1993) (striking regulation excluding people convicted of a crime of force, violcnce, or moral turpitude from the state's list of towing contractors). But cf. Blackburn v. City of Marshall, 42 F.3d 925 (5th Cir. 1995) (finding no property interest in remaining on towing on-call list where removal procedure not specified in regulation).

I56. But cf. Elena Saxenhouse, Unequal Protection: Comparing Former Felons' Challenges to Disenfranchisement and Employment Discrimination, 56 STAN. L. REV. 1597 (2004) (arguing that courts review collateral consequences with more consistent and robust rational-basis review than disenfranchisement statutes).

157. See Brandt v. Fox, 153 Cal. Rptr. 683 (Ct. App. 1979) (reversing denial of real estate license for 1974 conviction for distribution of a controlled substance); Brewer v. Dep't of Motor Vehicles, 155 Cal. Rptr. 643 (Ct. App. 1979) (reversing revocation of convicted sex offender's license to sell cars); People v. Lindner, 535 N.E.2d 829 (Ill. 1989) (rcversing revocation of sex offender's driver's license for lack of adequate nexus between denial of government bencfit and government interest).

158. See Comings v. State Bd. of Educ., 100 Cal. Rptr. 73 (Ct. App. 1972) (finding school district's discharge of teacher solely for one marijuana possession conviction arbitrary and capricious while upholding similar discharge where significant cvidence of teacher's unfitncss to teach also presented).

159. See Schware v. Bd. of Bar Exam'rs, 353 U.S. 232 (1957) (reversing state bar's denial of applicant's registration for bar exam on basis of arrests at labor demonstrations that did not lead to conviction, use of aliases to avoid anti-Semitism, and membership in Communist Party).

160. See Carr v. Thompson, 384 F. Supp. 544 (W.D.N.Y. 1974) (reversing denial of application to take civil service examination to become an assistant filter operator for city of applicant with juvenile conviction records sixteen years old at time of application); Bell v. Waterfront Comm'n of N.Y. Harbor, 228 N.E.2d 758 (N.Y. 1967) (reversing denial of occupational license to longshoreman with ten-year-old juvenile conviction for perjury). 
In addition to being treated as a non-suspect group, ex-offenders challenging collateral consequences often cannot invoke heightened scrutiny on the basis of fundamental rights. Collateral consequences infringe on many aspects of an ex-offenders' life from education to employment to housing, as described above, but (felon disenfranchisement aside) since most of these infringements are social or economic in nature, they violate no fundamental right for equal-protection purposes. While employment in the "common occupations" is considered a liberty interest protected by the due process clause, ${ }^{161}$ it does not rise to the level of a fundamental right for purposes of equal protection. Even restrictions on ex-offenders' right to vote, which is a fundamental right, do not trigger heightened scrutiny, according to the Supreme Court in Richardson v. Ramirez. ${ }^{162}$ As described in detail in section IV.C. 3 below, the Court justified its holding by interpreting Section Two of the Fourteenth Amendment in light of the original intent of its authors. ${ }^{163}$ Section Two creates a representational penalty for states that disenfranchise otherwise eligible voters by reducing their representation in the House of Representatives by the proportion of excluded to non-excluded voters. Significantly, Section Two makes an exception to the representational penalty for states' exclusion of persons convicted of "rebellion, or other crime;"'164 the Ramirez Court interpreted this to mean that infringements on ex-offenders' fundamental voting rights should not trigger heightened scrutiny. The Court reasoned that the framers of the Fourteenth Amendment could not have intended to outlaw by the Equal Protection Clause in Section One the very disenfranchisement allowed in Section Two. ${ }^{165}$

\section{A. How Ex-Offenders Meet the Criteria for Heightened Scrutiny}

Given the imprecision of the suspectness doctrine discussed above and the Court's usage of each new indicium of suspectness, the most logical way to make the case that ex-offenders are a suspect class is to address their qualification under each indicium. The following section will proceed through the indicia in a different order than the historical sequence used above. Since the immutability indicium, in particular its irrelevance to individual responsibility and ability strand, is the most problematic of the indicia for ex-offenders, this section will consider immutability first. In addition, since the Carolene Products formulation is so closely aligned with political powerlessness in the caselaw, this section will consider discreteness and insularity as part of the political powerlessness analysis.

\footnotetext{
161. See Truax v. Raich, 239 U.S. 33, 41 (1915).

162. 418 U.S. 24,54 (1974).

163. Id. at 41-56.

164. See U.S. Const. amend. XIV, § 2.

165. Ramirez, 418 U.S. at 55.
} 


\section{Ex-Offenders Are an Immutable Class \\ a. Unalterability}

In order for a class's trait to be objectionable under other strands of immutability, it must be sufficiently unalterable to create a real barrier to exit from the class. ${ }^{166}$ Since the ex-offender class depends on government action for its creation and existence, government policy determines the class's immutability. Thirty-two states currently allow ex-offenders no opportunity to clean up their criminal convictions. ${ }^{167}$ In the eighteen that allow some opportunity, convictions can be altered, ameliorated, and in rare instances erased altogether.

To take California as a case study, felony convictions for which the underlying conviction could have been charged either as a felony or a misdemeanor ("wobblers"), such as grand theft, ${ }^{168}$ may be reduced from a felony to a misdemeanor by post-conviction motion. ${ }^{169}$ Misdemeanors and felonies for which no prison time was served ("paper felonies") may also be set aside and dismissed ("expunged" in California terminology) upon successful completion of probation and, in certain cases, presentation of additional evidence of rehabilitation. ${ }^{170}$ California convictions may be pardoned by petition to the Governor. ${ }^{171}$ State arrest records ${ }^{172}$ can also be erased within one year of arrest upon proof that the arresting officer had no probable cause, or that the subject of arrest was factually innocent of the offense. ${ }^{173}$ The fact that criminal records in some states may be altered and in rare instances erased altogether suggests that perhaps the class of exoffenders is not immutable.

This conclusion would be unwarranted. Most alterations of criminal records in California, including even the gubernatorial pardon, do not erase a criminal record altogether and therefore allow an investigating party to view the underlying conviction. ${ }^{174}$ In addition, as described above,

166. See infra Section II1.B.2 analysis.

167. See infra Table 2 .

168. Cal. Penal Code $\S 489$ (b) (Deering 2006).

169. Cal. Penal Code $\S 17$ (b)(5) (Deering 2006).

170. Cal. Penal Code $\S 1203.4$ (Deering 2006).

171. Cal. Penal Code $\$ 4852.01$ (Deering 2006).

172. Arrests by federal agents may not be erased absent extraordinary circumstances. See, e.g., United States v. Schnitzer, 567 F.2d 536, 539 (2nd Cir. 1977) ("No federal statute provides for the expungement of an arrest record. Instead, expungement lies within the equitable discretion of the court, and relief usually is granted only in "extreme eircumstances."); see generally Deborah Sprenger, Annotation, Expunction of Federal Arrest Records in Absence of Conviction, 97 A.L.R. FED. 652 (2006) (describing federal statutes and caselaw regarding expungement of federal arrest records of exonerated detainees).

173. CAL. Penal Code $\S 851.8$ (Deering 2006) ("The law enforcement agency having jurisdiction over the offense, upon a determination that the person arrested is factually innocent, shall, with the concurrence of the district attorney, seal its arrest records ....") (emphasis added).

174. Successful motions to reduce a felony obviously leave a misdemeanor on the record. In the case of expungement, expunged convictions remain on an individual's record in perpetuity. CAL. 
alterations to criminal records are not always updated in the private records databases upon which private employers and others rely for their investigations. The only relief mechanism that does erase an event on one's criminal record from public view in California, the successful motion to erase an arrest, can only be characterized as extraordinary ${ }^{175}$ and simply does not apply to convictions. Furthermore, the fact that erasing a criminal conviction from one's criminal history or even shielding it from view of investigating parties is available in only sixteen states belies the mutability of criminal histories. ${ }^{176}$

Overall, only a fraction of states allow for some form of clearing of post-conviction records, and even those few states impose significant administrative and evidentiary hurdles to legally available remedies. Thus, having a criminal record qualifies as an unalterable classification for purposes of the suspectness inquiry.

\section{b. Relevance to Individual Responsibility}

As discussed, where a legal burden has little relationship to a class member's mdividual responsibility, the courts are more likely to find immutability and apply heightened scrutiny. Several considerations demonstrate that legal burdens based on ex-offenders' criminal histories have little to no relevance to ex-offenders' individual responsibility. First, adjudication in the criminal justice system, rather than legislative enactment, is the appropriate legal mechanism for holding criminals accountable for their crimes and achieving penological goals. Ex-offenders have by definition completed their sentences and should not be held responsible ad infinitum for their offenses. Second, even if one holds that completion of their criminal sentences does not liberate ex-offenders from responsibility for their crimes-i.e. that they remain responsible for their lawbreaking-the remaining responsibility of ex-offenders for their crimes is tremendously variable. The seriousness of their original offenses and their degree of rehabilitation will range from reformed shoplifters to unreformed child

PENal CODE $\$ 1203.4$ (Deering 2005) (providing no directive to law enforcement agencies to erase a conviction record after a petitioner wins a motion to expunge). A successful motion to dismiss and set aside a conviction, rather than removing the offense from an individual's criminal history, merely replaces "conviction" with the phrase "set aside and dismissed in furtherance of justice" under the disposition column of her rap sheet. Id.; East Bay Community Law Center, supra note 50. The individual becomes legally privileged to deny the conviction to private parties when asked whether she has ever been convicted of a crime, but a routine background check by a potential employer will nevertheless reveal the offense. CAL. PENAL CODE $§ 1203.4$ (Deering 2005); see generally John, supra note 44.

175. While statewide statistics on the number of successful motions to erase an arrest record are unavailable, its extremely high burden of proof (first, that the arresting officer did not have probable cause for the arrest and, second, that the arrestee was factually innocent of the offense triggering the arrest) suggests that the remedy is rarely available or employed.

176. Mukamal \& Samuels, supra note 5, at 1509-10. 
molesters. Third, the accident-of-birth formulation is not preclusive of according heightened scrutiny to classes that are immutable but not defined by birth.

\section{i. Individual Responsibility for Crimes is Assessed Through the Criminal Justice System}

Burdens based on ex-offenders' criminal histories have little relevance to ex-offenders' individual responsibility because, put simply, they are exoffenders. Ex-offenders have, by definition, completed the sentences levied on them by the criminal justice system. By the criminal justice system's own standards, ex-offenders have paid their debt to society.

Furthermore, collateral consequences of conviction poorly serve the penological goals of deterrence, denunciation, retribution, rehabilitation, and incapacitation. These are better pursued through the criminal justice system. Since the public is less aware of collateral consequences than it is of criminal sentences, collateral consequences have little deterrent value. ${ }^{177}$ Rather than denouncing ex-offenders publicly and then encouraging their reintegration into the community, collateral consequences "attach[] visible signs of moral inferiority" in a relatively anonymous administrative setting. ${ }^{178}$ Retribution is only as effective as its proportional and individualized application, yet collateral consequences mostly sweep generically. ${ }^{179}$ Collateral consequences inhibit rehabilitation by hamstringing exoffenders' ability to become productive members in social and economic life. ${ }^{180}$ Collateral consequences also fail to incapacitate repeat offenders since they can move freely throughout society. ${ }^{181}$

Lastly, in the Constitution's prohibition against bills of attainder, ${ }^{182}$ defined as "legislative act[s] which inflict punishment without a judicial trial," 183 the Constitution declares that punitive sanctions should be administered through the criminal justice system, with its attendant protections of right to counsel, trial by jury, and due process standards. "Thus the Bill of

177. Nora V. Demleitner, Preventing Internal Exile: The Need for Restrictions on Collateral Sentencing Consequences, 11 StaN. L. \& Pol'y REv. 153, 161 (1999).

178. Id. at 160 (quoting R. Paul Davis, The Mark of Cain: Some Subliminal Effects of Criminal Process, 44 SASKetchewan L. Rev. 219,219 (1980)).

179. Id.

180. Id.

181. At best, collateral consequences lower crime rates in certain sensitive areas of society, such as the jobsite and public housing, at the expense of dispossessing reformed ex-offenders. Equally likely, collateral consequences displace crime to more accessible areas and cause crime by denying legal economic opportunities to ex-offenders. While protecting sensitive areas is a dcsirable result, it can and should be achieved at a much lower social cost. Tailoring collateral consequences either by individual sentencing or by sphere- and offense-specific legislation allows appropriate safeguarding while minimizing criminogenic dispossession of ex-offenders.

182. U.S. ConST. art. 1, § 9, cl. 3 ( noting that "No Bill of Attainder . . shall be passed."); U.S. Const, art. $1, \S 10$, cl. 1 (prohibiting states from same).

183. Cummings v. Missouri, 7 I U.S. 277, 287 (1866). 
Attainder Clause... reflected the Framers' belief that the Legislative Branch is not so well suited as politically independent judges and juries to the task of ruling upon the blaineworthiness, of, and levying appropriate punishment upon, specific persons." 184 Prohibiting people from pursuing employment opportunities has long been deemed punitive. ${ }^{185}$ When the legislature itself punishes specified citizens, it denies this processual protection.

The apparent reasons for inclusion of the Bill of Attainder Clause resonate strikingly with the situation ex-offenders face in legislatures across the country. The Court quotes Alexander Hamilton, saying that:

Nothing is more common than for a free people, in times of heat and violence, to gratify momentary passions, by letting into the government principles and precedents which afterwards prove fatal to themselves. Of this kind is the doctrine of disqualification, disfranchisement, and banishment by acts of the legislature.... If the legislature can disfranchise any number of citizens at pleasure by general descriptions ... if it may banish at discretion all those whom particular circumstances render obnoxious, without hearing or trial, no man can be safe.... The name of liberty applied to such a government, would be a mockery of common sense. ${ }^{186}$

From Megan's Law to Three Strikes, anti-crime legislation follows a depressingly familiar rhythm-one beat behind the latest gruesome crime. From moral accounting, penological effectiveness and separation of powers perspectives, ex-offenders' criminal histories are poor proxies for individual responsibility and should be used to assign legal burdens only in narrow circumstances.

\section{ii. The Class of Ex-Offenders Exhibits Tremendous Variability in Moral Blameworthiness}

Even if the legal system rejects this argument and requires exoffenders to pay for their lawbreaking long after completion of their criminal sentences, the degree to which individual ex-offenders remain responsible for their crimes varies tremendously among ex-offenders. The argument that lawbreakers deserve whatever punishment they get, whenever they get it, for no other reason than that they broke the law is perverse and simplistic. First, this argument would justify making ex-offenders wear

184. United States v. Brown, 381 U.S. 437, 445 (1965). But cf. Thomas B. Griffith, Note, Beyond Process: A Substantive Rationale for the Bill of Attainder Clause, 70 VA. L. REv. 475, 498 (1984) (arguing that separation of powers rationale and historicist rationale fail to adequately define and limit the Bill of Attainder Clause; rather courts should use a substantive approach that limits the clause to protecting political activities from retroactive legislative burdens) [hereinafter Beyond Process Note].

185. Cummings, 71 U.S. at 321 n.19 ("Some punishments,' says Blackstone, 'consist in exile or banishment ... others induce a disability of holding offices or employments." ').

186. Brown, 381 U.S. at 444. 
a ball-and-chain, branding them, or prohibiting them from earning any income ever again. Breaking the law cannot justify punishment in perpetuity to any degree. By corollary, the kind of burden imposed on ex-offenders must be proportional to their responsibility for their crime. Ex-offenders' residual responsibility for their crimes must presumably be based on further retributive justification or the need for public safety responsive to exoffenders' incomplete rehabilitation. Both of these bases for ex-offenders' residual responsibility, however, lack uniformity across the class and require proportional application.

Ex-offenders' degree of rehabilitation would be essential in determining their rcsidual individual responsibility for their crimes, yet, the success of ex-offender rehabilitation and reintegration into society is a largely unresolved empirical question. The latest nationwide survey of recidivism, tracking ex-prisoners during 1983, revealed that over $66 \%$ committed a felony or serious misdemeanor within three years of completing their sentences. ${ }^{187}$ Whether this rate of recidivism reflects the incorrigibility of criminals or their lack of lawful opportunities upon release is the core issue. With the debate left unresolved, the answer to this question is determined by the personal beliefs of the inquirer. The notion that criminals deviate from social norms due to an evil nature is in tension with the belief that criminals are the product of their socioeconomic circumstances and political shortcomings. Most people lie somewhere along the middle of this belief spectrum. An assessment of the social science research on this subject is beyond the scope of this paper, but if we throw out the two extreme determinist positions-that criminals are incorrigibly evil on one end and are totally determined by their surroundings on the other-we are left with the reasonable scenario of a group of people more and less culpable, more and less able to return to productive social roles, and more and less likely to reeidivate.

Some tailored assessment of the appropriateness of a given collateral consequencc across the various classes of ex-offenders is thus unavoidable in a just accommodation of society's need to deter crime and to reintegrate its lawbreakers. For African Americans or people of Japanese origin, legal burdens are almost never relevant to their particular group characteristic. Heightened scrutiny is thus appropriate for all government action on the basis of race or national origin. The relevance of collateral consequences to an individual's criminal history, by contrast, varies widely among exoffenders. The relevance-to-individual-responsibility strand of immutability creates a doctrinal problem. It imports into the suspectness inquiry the case-by-case equal-protection inquiry itself, collapsing what should be a two-stage review.

187. Travis et al., supra note 12, at 1 (citing Al.len J. Beck \& Bernard E. Shipley, U.S. DeP't of Justice, ReCidivism of Prisoners Released in 1983 (1989)). 
The collapse occurs as follows. First, heightened scrutiny is the only instance in which judicial review will detect social or economic discrimination. Second, according to the relevance-to-individual-responsibility strand of immutability, heightened scrutiny can only be activated when judges find, ex ante, that members of a group rarely deserve to be singled out on the basis of their group-based characteristic. Where society develops a prejudicial consensus about the dangerousness of a certain group, as in the case of ex-offenders, the judiciary is vulnerable to declaring ex ante that this group virtually always deserves to be singled out by the government. When this happens, legislatures can punish and constrain ex-offenders with near impunity.

Group-burden relevance is part of the decision whether to apply heightened scrutiny for ex-offenders to detect social and economic discrimination against them. As social science continues to demonstrate, social and economic discrimination against ex-offenders is intense and widespread. ${ }^{188}$ Unless the judiciary analyzes group-burden relevance with an eye for social and economic discrimination, the judiciary will be blind to the pervasive discrimination against ex-offenders and never turn on the heightened scrutiny necessary to detect it in individual cases.

In addition to creating this catch-22, the moral-relevance inquiry here also inappropriately homogenizes a heterogeneous group. In order to meaningfully evaluate a specific law for how well it achieves a legitimate goal, a court must decide that laws burdening ex-offenders tend to be irrelevant to their responsibility for their offenses. Outside of the specific context of a given individual and a given law, this inquiry will turn on little more than a belief about whether generic criminals are deserving of generic legislative sanction. Groups lacking social, political, or economic power and subject to sporadic stigmatization will tend to be viewed in light of events leading to stigmatizing impulses. In the public eye, the generic criminal is likely to be the worst kind, and deserving legislative sanction. The current suspectness inquiry holds that criminal histories create a nearly automatic correspondence between ex-offenders' responsibility and legal burdens necessarily rests on this faulty generic view. The relevance-to-individualresponsibility strand of immutability glosses over the question at the heart of equal-protection analysis and turns a valuable protection of individual rights into an echo of stereotype.

One frequent counterargument to the demand for individual adjudication in equal protection is its cost. That counterargument is unavailable here because every ex-offender already receives an individualized sentencing proceeding. The mechanism for case-by-case adjudication is thus already available. The retributive justification for ex-offenders' residual responsibility cannot justify application of collateral consequences to all

188. See, e.g., supra notes 34-41 and accompanying text. 
ex-offenders any more than retribution justifies application of a single sentence against all convicted criminals. Furthermore, legislatively enacted retribution against a class of persons falls squarely within the Constitution's prohibition against bills of attainder.

\section{iii. Immutable Traits Need Not Be Accidents of Birth}

It is worth briefly repeating that the accident-of-birth immutability formulation does not stand for the principle that a trait must be an accident of birth in order to make the legal burden imposed upon a class irrelevant to its members' individual responsibility for their trait. Aliens, for example, receive heightened scrutiny, but their defining trait-lack of citizenshipis not an accident of birth. ${ }^{189}$ Rather, the accident-of-birth formulation stands for the principle that if a trait is an accident of birth, it is more likely irrelevant to the legal burdens placed in its name. This principle does not speak to traits that are not accidents of birth, and does not preclude a criminal history from being a morally irrelevant trait.

\section{c. Irrelevance to Individual Ability, Impermeability \& Immutability}

The relevance of ex-offenders' criminal histories to their individual abilities plays no significant part in their claim to immutability.

\section{d. Impermeability}

Ex-offenders are not literally an impermeable classification, as roughly one-quarter of the American population with criminal records could attest. The reality that poor people, people of color, and people with substance abuse and mental health problems are disproportionately represented among ex-offenders creates the equivalent of impermeabilitynamely a social gulf between people who commit crimes and government decision-makers, or what John Hart Ely has described as a "we-they" divide. ${ }^{190}$ Where such a gulf exists, legislators are less likely to consider that legislation creating a "we-they" divide would ever apply to themselves or their loved ones or that the impact of collateral consequences on the ability of ex-offenders to reintegrate into society could be devastating. The class of ex-offenders is functionally, if not actually, impermeable.

\section{e. Immutability: Conclusions}

The substantial barriers to exit from the class of ex-offenders, the lack of significant relevance between ex-offenders' criminal histories and their

189. See Graham v. Richardson, 403 U.S. 365 (1971).

190. John Hart Ely, The Constitutionality of Reverse Racial Discrimination, 41 U. CHI. L. REv. 723 (1973-74) (arguing that reverse race discrimination should not be subject to heightened scrutiny because a legislative majority imposing a "we-they" classification that disadvantages itself is unlikely to be a discriminatory classification). 
individual responsibility, and the impermeability of the class all support the conclusion that ex-offenders are an immutable class.

\section{History of Class-Based Discrimination}

Ex-offenders have always experienced class-based discrimination in the United States. In English common law and continental Europe, serious criminal offenders suffered "civil death," or loss of membership in society, including the right to make contracts, inherit, bring suit and vote. ${ }^{191}$ The United States, while never fully adopting civil death, provided for automatic dissolution of marriage, the denial of employment and other licenses, and the inability to make contracts or sue in civil court until the $1960 \mathrm{~s} .{ }^{192}$

Justice Rehnquist, in his majority opinion in Richardson v. Ramirez, describes the long history of felon disenfranchisement in America. At the time of the Fourteenth Amendment's passage, out of the thirty-seven states in the nation, ${ }^{193}$ twenty-nine had provisions in their constitutions which prohibited, or authorized the legislature to prohibit, persons convicted of felonies or "infamous crimes" from voting. ${ }^{194}$

The legal discrimination experienced by ex-offenders in American history is similar to that experienced by women and African Americans. In creating heightened scrutiny for classifications based on gender, the Supreme Court pointed to the similarity between the legal status of women and that of African Americans under the pre-Civil War slave codes. "Neither slaves nor women could hold office, serve on juries, or bring suit in their own names, and married women traditionally were denied the legal capacity to hold or convey property or to serve as legal guardians of their own children." ${ }^{195}$ Each of these restrictions on legal status has also been or continues to be imposed upon ex-offenders.

\section{Political Powerlessness}

The normal inquiry into a group's political powerlessness turns on whether that group is a "discrete and insular minority." 196 Section Two of the Fourteenth Amendment distorts the normal political-powerlessness inquiry with respect to ex-offenders because it explicitly contemplates the disenfranchisement, and thus the political powerlessness, of persons with criminal records. Although this Comment will ultimately address the

191. Black's Law Dictionary 428 (8th ed. 2004).

192. See Demleitner, supra note 177, at 154-55; Alec C. Ewald, "Civil Death:" The Ideological Paradox of Criminal Disenfranchisement Law in the United States, 2002 Wisc. L. Rev. 1045, 1059-64 (2002) (tracing the history of civil death from the medieval period through the present).

193. Elec. Reference Desk, Emory Sch. of Law, Amendments to the Constitution, http://www.law.emory.cdu/FEDERAL/usconst/amend.html (last visited June 26, 2006).

194. Ramirez, 418 U.S. at 48 n.14.

195. Frontiero, 411 U.S. at 685.

196. Carolene Products Co., 304 U.S. at 152 n.4. 
Section Two problem by elaborating its textual, structural, and historical flaws, setting the problem aside for now, let us first see whether or not persons with criminal records meet the criteria for "discrete and insular minorities."

\section{Discrete}

Discreteness is not often considered independently of insularity, ${ }^{197}$ although some commentators have provided independent analysis. Commentators have defined a group as discrete when it is "separate or distinct," 198 or "when its members are marked out in ways that make it relatively easy for others to identify them." 199 These definitions of discreteness make sense under the Carolene Products rationale for protecting minorities from the dangers of majoritarian politics in two ways. First, readily distinguishable minorities are easy to target for prejudicial treatment in the legislative process, and, second, they are easy to avoid getting to know (thus reinforcing the effects of impermeability of a suspect class).$^{200}$

Distinguishable traits were largely limited to physically identifiable traits prior to the advent of advanced recordkeeping and digital identities. Professor Louis Lusky's response to the Supreme Court's declaration in Graham v. Richardson that "[a]liens as a class are a prime example of a 'discrete and insular' minority" is emblematic of this framing of identity. ${ }^{201}$ Lusky argued that Anglophone aliens are arguably indistinguishable minorities, while aliens with heavy accents or of distinguishable ethnicities are noticeable minorities, only the latter are the discrete minorities the Fourteenth Amendment meant to protect. ${ }^{202}$

Lusky fails to acknowledge that identification need not be based on physical appearance, heavy accent or any other immediately obvious characteristic. While aliens and children of non-married parents may be physically indistinguishable from the rest of society in daily life, in moments where documentation of citizenship (as in voting) or legitimacy (as in probate cases) is necessary, these groups are readily identifiable.

With the advance of information technology, ex-offenders have become a more identifiable minority. While there is no way to tell a formerly incarcerated person from a person without a criminal history simply on the basis of appearance, given the easy and inexpensive access to people's criminal histories that information technology has made possible, as described in Section II.A above, investigating parties today can readily identify ex-offenders by their digital scarlet letter.

197. Ackerman, supra note 4, at 728-29.

198. Lusky, supra note 110 , at 1105 n.72.

199. Ackerman, supra note 4 , at 729.

200. ELY, supra note 117 at 161 .

201. Graham v. Richardson, 403 U.S. 365, 372 (1971).

202. Lusky, supra note 110 , at 1105 n.72. 
There is a second sense in which ex-offenders and aliens share vulnerability to prejudicial treatment through their discreteness. Facial indistinguishability, like discreteness, prevents one of the mechanisms for reducing prejudice towards stigmatized minorities, namely familiarity. ${ }^{203}$ Where media, culture or episodic hysteria demonizes a physically indistinguishable minority - as in this country's fears of Catholics taking over the government, ${ }^{204}$ homosexuality, or violent crime-there are few people who know from experience that these perceptions are heavily shaped by stereotype. Physical indistinguishability of feared minorities, in other words, can serve a similar alienating function as segregation of racial or ethnic minorities. Furthermore, since ex-offenders, aliens and illegitimates are ultimately distinguishable during key moments of opportunity for prejudicial action, the mechanism for discrimination is fully available.

Lastly, facial discreteness is a questionable criterion for heightened scrutiny since discrete minorities are in a better position than anonymous minorities in terms of political influence ${ }^{205}$ Since discrete minorities cannot avoid public prejudice, and since avoidance is therefore not an available strategy for responding to prejudice, discrete minorities are inore likely than anonymous minorities to turn to protest and political voice in the face of prejudice. Put simply, for facially discrete minorities, the flight response is unavailable, which makes them more likely to fight in response to threatening discrimination. As a descriptive model, the greater identifiability of ex-offenders for purposes of employment, housing, and welfare may partly explain their increased political activity in recent years. Overall, however, ex-offenders choose anonymity and political silence, due to the social stigma they face in publicizing their criminal histories. For formerly incarcerated individuals, then, the forces of social stigma incentivize political silence, despite its enormous social and economic costs.

\section{Insular}

Bruce Ackerman describes insularity as "the tendency of group members to interact with great frequency in a variety of social contexts." ${ }^{206}$ It is

203. See ELY, supra note 117 , at 163 ("Our stereotypes [regarding homosexuals]... are likely to remain fixed, given our obliviousness to the fact that people around us may well be counterexamples.")

204. This prejudice was evident not only in 20th century election of President John F. Kennedy, Jr., but also in the Declaration of Independence itself, which lists as one of the Colonists' grievances that England allowed Canada to remain Catholic under its rule, thus threatening colonial security. THE DECLARATION OF INDEPENDENCE para. 17 (U.S. 1776) ("He has combined with others to subject us to a Jurisdiction foreign to our Constitution, and unaknowledged by our Laws; giving his Assent to their Acts of pretended Legislation: ... For abolishing the free System of English Laws in a neighbouring Province [by the Canada Act of 1764], establishing therein an arbitrary Government, and enlarging its Boundaries so as to render it at once an Example and fit instrument for introducing the same absolute Rule into these Colonies").

205. Ackerman, supra note 4, at 730 .

206. Id. at 726 . 
a Carolene Products factor because of its effect on the familiarity of political majorities with minority groups, as described in Sections III.B.2 (immutability) and V.C.l (discreteness) above.

During their incarceration, of course, offenders constitute one of the most insular groups in society. In addition, it is during this experience that offenders obtain the education in criminality and preemptive violence that composes a major element of society's fear of ex-offenders and motivation to discriminate against them

Ex-offenders, however, are not an insular group. Once out of jail or prison, ${ }^{207}$ ex-offenders do not join their formerly incarcerated brothers and sisters in a tight knit geographic or social network. Rather, they step back into their former roles, as best as they are able, as members of various racial, ethnic, religious, local, regional, political, and familial communities. Rather than find community in their identity as ex-felons or misdemeanants, ex-offenders try as quickly as possible to shed this identity and reestablish former identities or move ahead to new ones. ${ }^{208}$

The diffuseness of ex-offenders should not remove them as candidates for heightened scrutiny. Of groups receiving heightened scrutiny, illegitimates also clearly lack insularity. Moreover, ex-offenders deserve heightened scrutiny for both broad reasons that insular groups receive it: on one hand, the political majority easily avoids becoming familiar with them and targets them for prejudicial treatment, while, on the other hand, exoffenders face higher barriers to achieving power in pluralist politics. ${ }^{209}$

For similar reasons to the ones described above regarding their anonymity, the diffuseness of ex-offenders also makes them greater objects of fear in society. A group that is widely distributed throughout society rather than concentrated in one enclave can be more threatening. While incarceration by design protects society by isolating and removing dangerous people from society, once ex-offenders are released, they re-enter society. ${ }^{210}$

207. This diffusion also applies to individuals merely under the supervision of the criminal justice system, as in probation.

208. To the extent that ex-offenders fail at reintegration and return to the "criminal underworld," their insularity derives from their status as active criminals, an identity that the judicial system should not, of course, provide with heightcned protection.

209. See, e.g., Donald A. Dripps, Criminal Procedure, Footnote Four, and the Theory of Public Choice; Or, Why Don't Legislatures Give a Damn About the Rights of the Accused?, 44 Syracuse L. REv. 1079 (1993) (explaining the lack of robust criminal procedural protections for the accused through the public choice model).

210. Given the serious decline of rehabilitation as a penological goal, this is perhaps an inevitable fear. See, Kansas v. Hendricks, 521 U.S. 346, 361-62 (1997) ("As a threshold matter, commitment under the Act does not implicate either of the two primary objectives of criminal punishment: retribution or deterrence."); Mistretta v. United States, 488 U.S. 361, 365-66 (1989) (tracing the decline of rehabilitation as a penological goal); Haney \& Zimbardo, supra note 10, at 712 18. Since on the one hand we cannot justify permanent incarceration and on the other we no longer believe criminals who serve their time are rehabilitated, we logically believe that by freeing the incarcerated we are releasing criminality in our midst. See Demleitner, supra note 177, at 159-60 ("Our 
Excessive media attention on crime inflames fears. Given these fears, the diffuseness of ex-offenders fuels legislative action against the class.

A prime example of this phenomenon can be found in the social anxiety surrounding released sex offenders. Society perceives sex offenders as fully irredeemable - they can simply never be safe members of our communities. ${ }^{211}$ The demand for publicly available sex offender registries reflects the public's desire to unmask the anonymous, to locate exactly where, in their midst, hidden threats reside and then socially isolate them within communities. Diffuseness and insularity of highly stigmatized groups are two sides of the same segregationist instinct.

As some commentators have argued, insular groups are also easier to organize than diffuse groups. ${ }^{212}$ Diffuse groups suffer from less group identification, more of a free-rider problem, higher organizational costs, and greater difficulty in identifying political leaders. In sum, an insular group is "more likely to form a political lobby peopled by credible leaders who remain in close touch with the insular constituency they represent," which of course gives an insular group greater influence in a pluralist political system. ${ }^{213}$

Ex-offenders should be accorded heightened scrutiny because their very diffuseness inflames the discriminatory animus and the political disempowerment that names and perpetuates them as targets for prejudicial treatment by the government.

\section{Inherent Suspicion}

Unlike racial, ethnic or sexual identity minorities, criminals are a group the government has many reasons to regulate. Penological goals of deterrence, retribution, incapacitation, and rehabilitation capture a range of government justifications for regulating criminals. With so many important government interests at stake, legislation targeting criminals is in a sense inherently unsuspicious.

Society easily but wrongly extends this inherent legitimacy to legislation targeting ex-offenders. With the demise or hibernation of rehabilitation as a goal of current penology, society no longer trusts that criminals who serve their sentences are reformed. As members of an unreformable class,

actual practice is to permit almost all criminals to return to society, in a physical sense, but to hold them off, make them keep their distance, segregate them in the midst of the ordinary community.") (quoting Edwin H. Sutherland \& Donald R. Cressey, Principles of Criminology 518 (5th ed. 1955)).

211. This despite the fact that nineteen out of twenty sex offenders do not commit another sex offense within three years of release and that their rates of re-arrest for any crimes are two-thirds that of other offenders. Patrick A. LANGan et al., Recidivism of Sex Offenders Released iN 1994 2, 24 (2003), available at http://www.ojp.usdoj.gov/bjs/abstract/rsorp94.htm. Furthermore, re-arrest rates of child molesters are even lower than those of other sex-offenders. Id. at 15.

212. Ackerman, supra note 4, at 722-28.

213. Id. at 727 . 
ex-offenders are considered criminals. If ex-offenders are criminals, then government is justified in regulating ex-offenders for penological purposes. $^{214}$

Setting aside the moral consideration that every individual deserves the opportunity to start over after paying for her wrongs, pragmatism suggests that punishing ex-offenders does not significantly further penological goals. $^{215}$ The strong government justifications for regulating criminals falter when applied to the regulation of ex-offenders. If the government chooses to pursue penological goals by regulating ex-offenders, it should be forced to closely tailor its efforts to concrete, verifiable goals.

Having made the case for why ex-offenders merit heightened scrutiny as a suspect class, this Comment now proceeds to consider the substantial objection that Section Two of the Fourteenth Amendment contemplates exoffenders' political powerlessness, and that it would therefore be untenable to afford ex-offenders heightened scrutiny on the basis of a constitutionally sanctioned disempowerment.

\section{$\mathrm{V}$ \\ The Section-Two Objection \\ A. The Problem Defined}

The Equal Protection Clause has grown dramatically beyond the protections the authors and framers of the Fourteenth Amendment contemplated. The Carolene Products decision led this expansion by abstracting the original rationales for protecting Freedmen from Southern state governments after the Civil War. The Framers were concerned with individual vulnerability to three types of government infringements which, according to Carolene Products' footnote four merit special judicial protection: first, government infringements on rights explicitly guaranteed by the Constitution; second, legal burdens placed on discrete and insular minorities; and third, government infringements on the rights necessary for political participation. Carolene Products and subsequent cases have been the basis for judicial intervention in the name of minority protections ranging from desegregation of public schools to giving resident aliens welfare benefits on

214. Professor Ely similarly transposes goals legitimate for regulation of criminals to regulation of ex-offenders when he argues that a prohibition against ex-burglars praetieing medicine would be justified by a deterrence rationale, so long as it is not imposed retroactively. ELY, supra note 118, at 154 n.65. He does acknowledge that criminals and presumably ex-offenders are a stigmatized minority and for that reason worthy of treatment as a suspect class. Id. At 153-54. He then sidesteps the issues of this Comment by arguing that laws targeting criminals and ex-offenders are so immediately justified by deterrence that any suspicion of prejudicial motivation "doesn't even have time to register." Id. This position ignores an essential problem: distinguishing when regulation of ex-offenders shades from legitimate governmental goal into legislative abuse.

215. See supra notes $172-176$ and accompanying text. 
the same terms as U.S. citizens, protections clearly beyond the specific vision of the framers of the Fourteenth Amendment.

For reasons described throughout this Comment, statutory and other restrictions burdening ex-offenders merit heightened judicial attention. Unlike other expansions of the Equal Protection Clause, however, this one faces text in Section Two of the Fourteenth Amendment that could be interpreted to prevent the judiciary from offering special protection to exoffenders.

Section Two of the Fourteenth Amendment states that:

Representatives shall be apportioned among the several States according to their respective numbers, counting the whole number of persons in each State, excluding Indians not taxed. But when the right to vote at any election... is denied to any of the male inhabitants of such State, being twenty-one years of age, and citizens of the United States, or in any way abridged, except for participation in rebellion, or other crime, the basis of representation therein shall be reduced in the proportion which the number of such male citizens shall bear to the whole number of male citizens twenty-one years of age in such State. ${ }^{216}$

The Supreme Court offered its most thorough interpretation of Section Two in Richardson v. Ramirez. In Ramirez, ex-felons in California challenged several California counties' refusal to accept their voter registration applications. ${ }^{217}$ The Court held that infringements on the right of ex-felons to vote should be exempted from the heightened scrutiny normally triggered by state infringements on this fundamental right. ${ }^{218}$ The Court reasoned that the Equal Protection Clause, contained in Section One of the Fourteenth Amendment, ${ }^{219}$ could not be applied to strike down voting restrictions against convicted criminals because Section Two contemplated and allowed precisely these voting restrictions. ${ }^{220}$ The Court found that the "plain reading" of the Fourteenth Amendment was reinforced by evidence of the framers' original intent as contained in the legislative history of its passage. ${ }^{221}$ Specifically, the Court cited concurrent state laws, constitutions,

216. U.S. CONST, amend. XIV, \& 2.

217. Ramirez, 418 U.S. at 26.

218. Id. at 54

219. U.S. CoNST, amend. XIV, § I:

All persons born or naturalized in the United States and subject to the jurisdiction thereof, are citizens of the United States and of the State wherein they reside. No State shall make or enforce any law which shall abridge the privileges or immunities of citizens of the United States; nor shall any State deprive any person of life, liberty, or property, without due process of law; nor deny to any person within its jurisdiction the equal protection of the laws.

220. Ramirez, 418 U.S. at 55 ("[W]e may rest on the demonstrably sound proposition that $\S 1$, in dealing with voting rights as it does, could not have been meant to bar outright a form of disenfranchisement which was expressly exempted from the less drastic sanction of reduced representation which $\S 2$ imposed for other forms of disenfranchisement.").

221. Id. at 43-53. 
and legislative history of federal statutes to argue that the authors of the Fourteenth Amendment intended states to retain the authority to disenfranchise ex-felons. ${ }^{222}$

Section Two poses a problem to this Comment's heightened scrutiny claim. The Constitution contemplates and allows states to disenfranchise ex-offenders. Disenfranchisement is one of the most direct ways to politically disempower a group. Allowing states to politically disempower exoffenders constitutes approval of their political powerlessness. For the Constitution to approve the political powerlessness of ex-offenders while at the same time demanding heightened judicial protection of ex-offenders on the basis this same political powerlessness would be a logical contradiction (the "Section Two Argument"). The Section Two Argument, however, wrongly extrapolates from the historical fact of disenfranchisement a rationale for deprivation of heightened protection of individual rights.

\section{B. Rebuttal}

The Section Two Argument's fatal flaw is a conflation of the Constitution's approval of political powerlessness with approval of unchecked government prejudice towards the politically powerless.

The text and structure of the Constitution, the intent of the framers of the Fourteenth Amendment, and the array and flow of individual rights in the late-nineteenth century all reveal the basic fallacy of the Section Two Argument: constitutional approval of political powerlessness of exoffenders or any other group is in no way commensurate with approval of government prejudice towards the politically powerless. While the framers employed justifications to substantiate the deprivation of political power from certain groups at the time of passage of the Fourteenth Amendment, the framers removed indiscriminate denial of individual rights by government from the realm of justifiability. The framers' apparent approval of exoffenders' political disempowerment should therefore not detract from the framers' intent to protect all persons from government abuse. Similarly, the framers' apparent approval of ex-offenders' political disempowerment should not detract from the judicial protection that ex-offenders otherwise merit today.

\section{Text and Structure of the Constitution}

The most literal reading of Sections One and Two refutes the Section Two Argument. Although Ramirez interpreted the exception clause of Section Two ("for rebellion, or other crime"223) (hereinafter, the "Exception Clause") to bar meaningful equal-protection challenges to felon disenfranchisement statutes, the explicit exemption in Section Two "for rebellion, or

222. Id.

223. U.S. ConST. amend. XIV, § 2. 
other crime"224 is conspicuously absent from Section One. Since, as discussed in Section V.2.b below, the framers intended Sections One and Two to create distinct protections, had the framers wanted to exclude exoffenders from the ambit of Equal Protection or otherwise limit their eligibility under equal protection, they would have included an exception clause in Section One.

Furthermore, the federalist structure of the Constitution separates the authority to delimit a group's political power from the authority to review violations of the rights of individuals in a group. The Constitution vests the former authority in the states by the Tenth Amendment, ${ }^{225}$ and the latter in the federal government by the Fourteenth Amendment. At the time of passage of the Fourteenth Amendment, the Constitution allowed states to delimit the power of any group, includimg ex-offenders, women, men under twenty-one years of age, and aliens. ${ }^{226}$ This delegation of authority to define the franchise, however, did not reduce the protection from government discrimination that the federal government accorded to groups that states chose to disempower. Had states chosen, for example, to disenfranchise White males between the ages of thirty and thirty-five, the rights of this group under equal protection of the laws would have remained unchanged because states' use of their authority to define their political community cannot reduce the federal government's authority to protect individual rights under the principles of federalism. ${ }^{227}$ Equating constitutional approval of political powerlessness with approval of greater vulnerability to government discrimination ignores the fundamental divide between authority over these individual rights.

Additionally, the Equal Protection Clause, according to Carolene Products, protects suspect classes because they are easy targets of government abuse, historically discriminated against, and politically powerless.

224. Id.

225. "The powers not delegated to the United States by the Constitution, nor prohibited by it to the States, are reserved to the States respectively, or to the people." U.S. CoNST, amend. X.

226. Since the Constitution did not grant the federal government authority to define the franchise, states retain it by force of the Tenth Amendment. Thus, without a Constitutional amendment guaranteeing a group's right to vote, states are free to disenfranchise that group. By July 9, 1868, the date of ratification of the Fourteenth Amendment, Constitutional amendments to guarantee the right to vote had not been passed for Freedmen, women, people unable to pay poll taxes, or youth eighteen to twenty years old. The Fifteenth Amendment (granting all races the right to vote) was ratified on February 3, 1870; the Nineteenth (granting women the right to vote) on August 18, 1920; the TwentyFourth (abolishing poll taxes) on January 23, 1964; and the Twenty-Sixth (lowering the voting age to eighteen) on July 1, 1971. U.S. ConsT., amends. XV, XIX, XXIV, XXVI.

227. See Sugarman v. Dougall, 413 U.S. 634, 642-43 (1973) ("We recognize a State's interest in establishing its own form of government, and in limiting participation in that government to those who are within 'the basic conception of a political community.' We recognize, too, the State's broad power to define its political community. But in seeking to achieve this substantial purpose, with discrimination against aliens, the means the State employs must be precisely drawn in light of the acknowledged purpose.") (citation omitted) (emphasis added). See also McCulloch v. Maryland, 17 U.S. 316 (1819). 
That the Constitution contemplates and apparently approves the political powerlessness of ex-offenders does not, however, mean that the Constitution approves their status as targets of social condemnation or their prejudicial treatment by government. In fact, the Constitution contemplates the political powerlessness of every non-organized political minority in enacting a majoritarian democracy, but this does not mean the Constitution sanctions prejudicial government treatment of these groups. Political inequality is clearly accepted in American constitutionalism; inequality of oppressive legal burdens, however, is not.

The comparison between ex-offenders and aliens further illuminates the role of disenfranchisement with respect to the suspectness inquiry in equal protection. Aliens' suspect status is, like ex-offenders', legally constructed and imperfectly immutable. Furthermore, it is hard to argue that the history of class-based discrimination suffered by aliens is significantly more punishing than that experienced by ex-offenders. In light of the balancing nature of the suspectness inquiry, the fact that aliens lack the right to vote in this country cannot cut against the argument for their suspect status, ${ }^{228}$ but must rather operate to support it. ${ }^{229}$ Thus, where a politically powerless minority with a proven history of prejudicial government treatment can demonstrate that it is a likely target of government prejudice, that group should be accorded heightened judicial protection.

Lastly, the Constitution prohibits bills of attainder. ${ }^{230}$ As the Supreme Court explained in 1866,

a bill of attainder is a legislative act which inflicts punishment without a judicial trial.... [In enacting bills of attainder,] the legislative body ... exercises the powers and office of judge; it assumes . . judicial inagistracy; it pronounces upon the guilt of the party, without any of the forms or safeguards of trial ... and it

228. Hampton v. Mow Sun Wong, 426 U.S. 88, 102 (1976) ("The rule [prohibiting employment of aliens by the federal government] ... has its impact on an identifiable class of persons who, entirely apart from the rule itself, are already subject to disadvantages not shared by the remainder of the community. Aliens are not entitled to vote ....") (emphasis added). Cf. TriBe, supra note 3, $\$ 16-23$ ("That aliens do not vote might be seen as demonstrating their lack of political power; but, at least if it is alien disenfranchisement that is being challenged, it would seem oddly circular to rely on the very practice challenged to establish the propriety of so strictly scrutinizing it as to make very probable its invalidation."). As argued above, however, this apparent cireularity is in fact the operation of federalism's distribution of authority between the states and the federal government: while states may define the franchise the federal government may protect individuals from unequal treatment under state laws. Disenfranchisement, in other words, can logically play different roles in the operation of distinct authorities motivated by separate purposes.

229. Unless of course ex-offenders are equally or more deserving of heightened scrutiny under a consistent application of the Equal Protection Clause, and their exclusion is simply the product of the Burger Court's freezing of development of the doctrine.

230. U.S. ConST. art. I, $\S 9$, cl. 3 (prohibiting Congress); U.S. Const. art. 1, § 10, cl. 1 (prohibiting states). 
fixes the degree of punishment in accordance with its own notions

of the enormity of the offence. ${ }^{231}$

The Bill of Attainder Clause stands for the principle that specific individuals and classes of individuals undergoing punishment by the government are entitled to the protections guaranteed to defendants in the criminal justice system. ${ }^{232}$ When legislatures target specific individuals or classes of individuals for punishment through the legislative process, they violate the Constitution's separation of powers. ${ }^{233}$ Although the Bill of Attainder Clause does not apply directly to the political-powerlessness inquiry of a potential suspect class, it does stand for an important constitutional value, namely, individual freedom from persecution for past actions outside of the criminal justice system. ${ }^{234}$

\section{Framers' Intent}

In order to expand the holding in Ramirez to prevent the application of heightened judicial scrutiny to ex-offenders, the Court would have to argue that implied in the Amendment's approval of disenfranchisement of exoffenders is approval of virtually unchecked government discrimination against them. This position lacks Ramirez's textual foundation and requires a secondary investigation into legislative intent as to the broad status of exoffenders in civil society. ${ }^{235}$

231. United States v. Cummings, 71 U.S. 277,323 (1866).

232. United States v. Brown, 381 U.S. 437, 442 (1965) ("[T]he Bill of Attainder Clause was intended . . . as an implementation of the separation of powers, a general safeguard against legislative exercise of the judicial function, or more simply-trial by legislature.").

233. See id. (striking down as legislatively enacted punishment a federal statute that barred current and former members of the Communist Party from serving as union officials).

234. See Note, Making Outcasts Out of Outlaws: The Unconstitutionality of Sex Offender Registration and Criminal Alien Detention, 117 HARv. L. REv. 2731, 2751 (2004) (arguing that Bill of Attainder Clause, Equal Protection Clause, and privacy rights create a constitutional norm against government degradation of sex-offenders and criminal aliens); see also Akhil Reed Amar, Attainder and Amendment 2: Romer's Rightness, 95 Mich. L. Rev. 203 (1996); Daniel Farber \& Suzanna Sherry, The Pariah Principle, 13 Const. COMment. 257 (1996).

235. This Comment does not offer evidence of history and legislative intent to suggest in any way that the Constitution should be bound by the original intent of its authors and amenders or to engage in the debate over the original intent of those who passed and ratified the Fourteenth Amendment. Divining original intent with respect to Constitutional amendments is complicated by an extreme version of a common problem in interpreting legislative intent, namely, whose intent counts. In this case, it is not clear that the intent of the Congressional authors or framers of the Fourteenth Amendment should trump that of its twenty-eight ratifying bodies. Giving the Ramirez decision, however, the benefit of the doubt, this Comment will assume arguendo that the intent of the authors or framers of the Fourteenth Amendment constitutes its legislative intent.

Expansion from the textual justification in Ramirez also creates a classic original-intent problem, namely identifying which original intentions to honor and preserve and which to discard. The framers of the Fourteenth Amendment, for example, would not likely have expected heightened application of equal protection to women, children of unmarried parents, or aliens. Although the level of scrutiny applied to these suspect classes today is not strict scrutiny, the Burger and Rehnquist Courts have upheld heightened scrutiny for all of these groups. 
The Framers intended the Equal Protection Clause to protect from state government infringement only a narrow band of Freedmen's rights, namely their "civil" rights. The right to vote was not among these civil rights and was not guaranteed for Freedmen until ratification of the Fifteenth Amendment. The fact that the authors of the Fourteenth Amendment vicwed civil rights as independent from political rights suggests that the sanction of political powerlessness of ex-offenders should not be viewed as limiting equal protection of ex-offenders' rights from government attack.

The Civil Rights Act of 1866 aimed to end state discrimination on the basis of race in making contracts, bringing lawsuits, and enjoying "full and equal benefit of all laws and proceedings for the security of person and property." 236 The Republicans, who commanded the overwhelming majority in the Reconstruction Congress, viewed these rights as civil rights essential for the Freedmen to negotiate and enforce contracts for their work and to avoid being coerced and manipulated back into conditions of slave labor. ${ }^{237}$ Exercising economic independence by making legally enforceable contracts and being secure in one's person and property, then, constituted the dominant conception of civil rights at the time of Reconstruction. ${ }^{238}$

President Andrew Johnson vetoed the Civil Rights Act of 1866. But in contrast to the Freedman's Bureau Act, which the President had vetoed earlier that year, Congress was able to override the President to pass the Civil Rights Act. Given the animosity of their president and his constant efforts to readmit Southern representatives into Congress, Republicans sought to embed civil protections in the Constitution. The Civil Rights Act of 1866 became the gencsis of the Fourteenth Amendment.

Neither the Civil Rights Act of 1866 nor the Fourteenth Amendment gave Freedmen the right to vote. Giving Freedmen the right to vote required the exercise of considerably more coercive federal authority than moderate Republicans were willing to exert on the South in the first half of $1866 .{ }^{239}$ Furthermore, the North was itself both segregated and White supremacist. ${ }^{240}$ Granting social equality to Freedmen was thus out of the

236. See ERIC Foner, RECONSTRUCTION 243 (1988). Justice Harlan's partial dissent in Oregon v. Mitchell, 400 U.S. 112, 152-200 (1970), also relates the history that follows in close detail.

237. Id. at 244.

238. See Foner, supra note 236.

239. See id. at 251-55.

240. See C. Vann Woodward, The Strange Career of Jim Crow 17-21 (2d rev. ed. 1966) (quoting, in addition, Abraham Lincoln in an 1858 speech to reveal with devastating clarity the preCivil War perspective of moderate Republicans on racial equality: "I will say then that I am not, nor ever have been in favor of bringing about in any way the social and political equality of the white and black races [applause] ... and I will say in addition to this that thcre is a physieal difference between the black and white races which I believe will forever forbid the two races living together on terms of social and political equality. And inasmuch as they cannot so live, while they do remain together there must be the position of superior and inferior, and I as much as any other man am in favor of having the superior position assigned to the white race."). 
question in the minds of most Republicans, and even granting political equality was a major infringement on the status quo. ${ }^{241}$

By their disinclination to give Freedmen political equality, Republicans forced themselves into a political quandary: once admitted to Congress, Southern states would gain substantially more representation than before the Civil War because, while former slaves counted only threefifths for purposes of Congressional representation, Freedmen would count fully. The most obvious solution was giving Freedmen the right to vote, but in an attempt to have their cake and eat it too, Republicans devised Section Two of the Fourteenth Amendment. ${ }^{242}$ Section Two would penalize states that did not grant Freedmen the franchise by reducing the states' representation in Congress. The number of states' Congressional representatives would be reduced in the same proportion that the states disenfranchised their otherwise eligible voting population. Since Southern states would disenfranchise more Freedmen than Northern states, Section Two, it was thought, would preserve the pre-Civil War balance of Congressional representation.

Section Two was a compromise measure both in the sense that it gave recalcitrant Southern states an incentive to enfranchise Freedmen without forcing them to do $\mathrm{so}^{243}$ and in the sense that it did not force entrenched Northern states to enfranchise Freedmen. It preserved some of the North's representational advantage derived from the three-fifths compromise. This suggests the framers of the Fourteenth Amendment did not intend that groups that could be denied the right to vote could also be denied civil rights. To the contrary, the framers specifically designed the Fourteenth Amendment to guarantee Freedmen civil equality without extending political equality. ${ }^{244}$ Extrapolation from the Framers' sanction of unchecked state disenfranchisement of criminals to a broader sanction of unchecked state deprivation of their other rights is unwarranted. ${ }^{245}$

Furthermore, in addition to reflecting the framers' distinct conceptions of civil and political rights, the Exception Clause was an expedient to the

241. In 1860, only five states-Massachusetts, Vermont, New Hampshire, Maine and Rhode lsland-allowed free African Americans to vote. Id. at 20.

242. See FONER, supra note 236, at 252.

243. Id.

244. But see Oregon v. Mitchell, 400 U.S. 112, 229 (1970) (Brennan, J., dissenting in part).

245. A further argument that the framers did not intend wholesale disempowerment and subjection of ex-offenders to unequal treatment of the laws is based on the interpretation that the primary concem of the framers in Section Two was to create an incentive for states to give Freedmen the franchise rather than to address the political powerlessness of ex-offenders. As the Ramirez Court concedes, "the framers of the Amendment were primarily concerned with the effect of reduced representation upon the States, rather than with the two forms of disenfranchisement which were exempted from that consequence by the language with which we are concerned here." Ramirez, 418 U.S. at 43 . One could argue that Section Two relegates a group secondary to its clear purpose to unchecked state discrimination. The oblique, almost offhand quality of the section's reference to traitors and criminals, however, belies the claim that the framers intended a sweeping demotion of these groups. 
passage of the Fourteenth Amendment, given the political dynamics of the first half of 1866 . Since states retain the power to define the franchise by force of the Tenth Amendment and most states disenfranchised exoffenders in $1866,{ }^{246}$ the framers would have forccd states to rewrite their constitutions to give ex-offenders the franchise had the framers failed to include the Exception Clause.

Forcing states to enfranchise ex-offenders or suffer a representational penalty would have been controversial in its encroachment of federal authority onto the states' power to define the franchise. Since Section Two was a compromise measure by moderate Republicans shy about use of excessive federal coercion, the mild nature of Section Two's exertion of federal authority suggests that failure to include the Exception Clause would have been an omission too radical for moderate Republicans in the first half of 1866. It is therefore reasonable to conclude that exclusion of the Exception Clause from Section Two would have prevented passage of the Fourteenth Amendment altogether. Given that the framers' primary goal in Section Two was to better the lot of Freedmen rather than that of exoffenders, it would have been counterproductive for the framers to demand Southern states grant ex-offenders the franchise.

Despite Republicans' tentativeness about infringing on states' rights to define the franchise, they passed the Fourteenth Amendment to impose considerable additional federal authority over Southern states' treatment of Freedmen. Considering the fact that Freedmen were the most likely candidates for wrongful criminal prosecution in the South, a loophole in federal oversight of states' treatment of civil rights of ex-offenders would constitute a truly remarkable lack of foresight on the part of the Framers. ${ }^{247}$ More likely, the Framers intended to give the federal government the authority to protect ex-offenders' civil rights.

\section{Inconsistent with Late-Nineteenth History}

The history of the late nineteenth century further demonstrates that the framers would have viewed voting rights independently from other rights.

To begin, different rationales animated distribution of the right to vote and the right to equal protection. The right to vote in early American history was rooted in a republican theory of government and depended on the

246. Ramirez, 418 U.S. at 29 (1974) (noting that twenty-nine states disenfranchised or empowered their legislatures to disenfranchise ex-offenders in 1866).

247. The Thirteenth Amendment abolishes slavery and involuntary servitude "except as a punishment for crimc whereof the party shall have been duly convicted." This exception could be interpreted as an example of the Framers' lack of coneern for the rights of criminals and expanded as a rebuttal to the argument advanced here. That slavery and involuntary servitude are allowed "as punishment" for a criminal conviction belies this interpretation. This language suggests the exception was included in order to preserve imprisonment and other physical detentions as a criminal sentencing option rather than in order to condone a permanent stripping of all a defendant's civil rights upon conviction. 
fitness of groups to responsibly participate in representative democracy, ${ }^{248}$ while the right to protection from government discrimination did not vary according to the capacities of groups-"all persons" deserved it, even women and men under twenty-one. ${ }^{249}$ Political powerlessness thus plays two different Constitutional roles. In the right to vote, political powerlessness is a potential result of states' use of their authority to define their own political community under federalism's distribution of that authority. In today's right to equal protection, however, political powerlessness is a marker of groups more likely to be subject to government abuse. That the framers accepted states' authority to define the franchise, and even that the framers considered ex-offenders unfit to vote, would not have impeded the application of equal protection to ex-offenders and should not limit the marking function that political powerlessness plays in the heightened scrutiny inquiry.

The historical record also demonstrates that the arrays of rights of different groups in the second half of the nineteenth century varied in ways unrelated to a given group's right to vote. The economic rights of women in the decades before the Fourteenth Amendment, for example, began to change radically despite their continued disenfranchisement. Traditionally, women forfeited most independent property and contracting rights upon marriage. Beginning in 1837 with Mississippi, however, states began to pass married women's property acts in order to respond to women's greater role in the formal economy. The increased use of credit and the familial pauperization that a husband's poor business fortunes could precipitate drove the need for married women's greater property rights. ${ }^{250}$ In fact Virginia was the only state lacking a married women's property clause in its constitution after the forced rewriting of Southern state constitutions under Reconstruction. ${ }^{251}$

Similarly, Chinese immigrants in the late nineteenth century could not vote and were the focus of an intense racist and nativist attack. Even in the midst of this intense societal attack, however, the Supreme Court protected the economic rights of Chinese laundry owners against unequal treatment by the San Francisco Board of Supervisors in issuing laundry operating permits. ${ }^{252}$

Even the rights of criminals, whose voting rights were consistently nonexistent, underwent a significant expansion during Reconstruction, through the Habeas Corpus Act of 1887. The Act gave people incarcerated

248. See Ewald, supra note 192 at 1061-63

249. "No State shall make or enforce any law which shall... deny to any person within its jurisdiction the equal protection of the laws." U.S. CONST. amend. XIV, § I (emphasis added).

250. Kermit Hall et al., American Legal History 267 (2d ed. 1996).

251. See FonER, supra note 236, at 320; Suzanne D. Lebsock, Radical Reconstruction and the Property Rights of Southern Women, 43 J.S. HIST. 195, 195-197 (1977).

252. Yick Wo v. Hopkins, 118 U.S. 356 (1886). 
under state authority access to federal-court review of their conviction, which required a massive expansion of federal judicial power over state courts. $^{253}$

The historical record of the distribution of social, economic and political rights in the late-nineteenth century affirms that the Framers are unlikely to have assumed or intended a simple equivalence between political disenfranchisement and absence of judicial review of government action, particularly towards a group likely to be on the receiving end of significant prejudice.

\section{CONCLUSION}

In arguing that ex-offenders should be treated as a suspect classification, this Comment does not suggest that all government action naming exoffenders be reviewed by the judiciary under strict or fatal-in-fact scrutiny. Rather, what equal protection demands of the judiciary is scrutiny sufficient to evaluate whether the government imposed a given collateral consequence largely as a punitive measure without careful consideration of its policy implications or appropriate tailoring of the measure to apply only to ex-offenders who present a real risk to public safety.

As discussed above, ${ }^{254}$ some courts have applied what appears to be rational basis with teeth to collateral consequences of conviction. Under these analyses, collateraI consequences that take away substantial social or economic opportunities from ex-offenders for relatively minor recorded criminal activity (e.g., arrests not leading to convictions, drug possession) or dated criminal activity are not adequately tailored even to weighty government interests (e.g., teaching children). Furthermore, some states have passed statutes requiring employers to consider evidence of rehabilitation in a job applicant with a criminal history and whether her history is directly or substantially related to the job position being sought. The Equal Employment Opportunity Commission has also suggested that employers evaluating minority job applicants must consider: (1) the nature and gravity of the offense, (2) the time passed since the conviction and/or completion of sentence, and (3) the nature of the job held or sought. ${ }^{255}$ These initial steps by some courts, legislatures, and executive agencies suggest the contours of a more robust right of ex-offenders to equal protection of the laws.

A robust equal-protection doctrine would likely effect several changes. First, by demanding from government a substantial justification for imposition of collateral consequences imposed, courts would require

253. See William M. Wiecek, The Reconstruction of Federal Judicial Power, 1863-1876, in American LAw AND The Constitutional Order 237 (Lawrence M. Friedman \& Harry N. Scheiber eds., 1978).

254. See supra notes $98,99,149-163$ and accompanying text.

255. CCH lnc., I EEOC Compliance Manual $\S 604.10 \uparrow 2088$ (2005). 
government decision makers to consider carefully the denial of discretionary benefits such as public employment, occupational licenses, and public housing. Second, state laws denying drivers' licenses to ex-offenders would be declared unconstitutional for lack of a nexus to public safety in all but a narrow range of ex-offenders (e.g., those convicted of drunk driving and still in rehabilitation). Third, exclusion of drug offenders from the TANF and Food Stamps programs would be vulnerable to legal attack in the same way that denial of welfare benefits to aliens was attacked in Graham v. Richardson: ${ }^{256}$ preservation of administrative resources is an insufficient justification for government prejudice against vulnerable minorities.

Heightened scrutiny might also lead to court tailoring of overly broad government dissemination of criminal record information for purposes of employment. Courts might eliminate releasc of old criminal history information to employers and require a meaningful relationship between type of employment and type of criminal history.

Compelling individual arguments are available to make the case for ex-offenders in each of the four criteria for application of heightened scrutiny. Stepping back from the individual arguments, however, there is a broader framework for why ex-offenders should be protected with heightened scrutiny.

The constitutional mechanisms for ensuring proportionality, or at least limiting disproportionality, of legal burdens placed on ex-offenders simply fail to protect them. The Eighth Amendment prohibits cruel and unusual punishments, but only applies to a narrow band of punishments. The Bill of Attainder Clause prohibits legislative punishments apart from the judicial system for past conduct of specific individuals or members of readily identifiable groups. Although some commentators argue that Romer v. Evans was in fact a bill of attainder case, ${ }^{257}$ to date the Supreme Court has only struck down four statutes for ostensible violation of the Bill of Attainder Clause. ${ }^{258}$ Lastly, in most cases where a legal burden exceeds the moral relevance of a group's status, the group will organize in the political arena to address the excess.

For ex-offenders, insuperable barriers to broad-based political organization exist. As the political-powerlessness discussion above suggests,

\footnotetext{
256. 403 U.S. 365 (1971).

257. Amar, supra note 234.

258. Beyond Proccss Note, supra note 184; United States v. Brown, 381 U.S. 437 (1965) (striking down as legislatively enacted punishment a federal statute that barred current and former members of the Communist Party from serving as union officials); United States v. Lovett, 328 U.S. 303 (1946) (striking law excluding three named persons considered subversive by House of Representatives from payment as federal employees); Ex parte Garland, 71 U.S. 333 (1867) (striking federal statute requiring attorneys practicing in federal court to submit to loyalty oath to new federal union); Cummings v. Missouri, 71 U.S. 277 (1866) (striking down provision of Missouri Constitution requiring loyalty oath to federal union in order to practice certain state-licensed professions).
} 
ex-offenders lack the means and political legitimacy to enter the legislative arena as a significant force - they are an example of repeat losers in the political process. Without political voice, ex-offenders cannot be their own advocates in the social and political dialogue about how to deal with exoffenders' community re-entry. While professors, experts, and occasional sympathetic politicians will turn their attention to the prejudice heaped on ex-offenders when the political climate is ripe, equal protection of the laws should not allow generally discriminatory treatment to be justified by occasional acts of surrogate advocacy. ${ }^{259}$ The second-best guarantee that lawmakers are not prejudicially discriminating against a suspect group is for courts to keep a close eye on the lawmakers. ${ }^{260}$ Due to ex-offenders' political impotence, ${ }^{261}$ burden after burden has been placed upon them.

This piling of legislative burdens onto a group that is already disproportionately marginalized along racial, educational, and economic lines has significantly handicapped ex-offenders as productive members of the economic and political life of this country. They have become second-class citizens. The Equal Protection Clause, according to Carolene Products, is supposed to protect "socially isolated minorities which have no reasonable hope of redress through the (formally available but, to them, useless) political processes."262 In the case of ex-offenders, however, the Equal Protection Clause only protects against legislation with no conceivable rational basis, which is protection in name only.

Since these constitutional mechanisms lay inert for ex-offenders, the appropriateness of their legal burdens remains unreviewed by policymakers. The legislative function is, in effect, not being carried out by the legislature. As such, rather than leaving punitive legislation essentially unconsidered, the judiciary should perform that function as part of a crucial safeguard of individual liberties. Rather than stepping on the toes of legislatures, courts here would be standing in for the vital role that legislatures too often abdicate.

259. This comment is not meant to demean the important and critical work of advocates on behalf of ex-offenders. Without them, the plight of ex-offenders would undoubtedly be far worse today. But as these advocates would probably be the first to admit, surrogate advocacy is no substitute for authentic empowerment.

260. The best guarantee, of course, is to empower suspect groups so that they themselves can reasonably protect their interests in the legislative arena.

261. There are scattered and notable exceptions to this trend. For example, a California nonprofit organization, All of Us or None, has enjoyed considerable success convincing municipal governments to limit their usc of criminal history information in public employment decisions. See Phillip Matier and Andrew Ross, New Bridge Span-Will It Be Made in China?, S.F. Chron,, Jan. 15, 2006, at B1; see also Editorial, Cities That Lead The Way, N.Y. Trmes, Mar. 31, 2006 at Al8 (praising Chicago, Boston and San Francisco for removing questions regarding prior convictions from initial applications for city employment).

262. Lusky, supra note 110 , at 1103 . 